\title{
TREASURES FROM THE WRECK OF THE UNBELIEVABLE - ARCHEOLOGIA JAKO ELEMENT STRATEGII ARTYSTYCZNEJ DAMIENA HIRSTA
}

\author{
For me, art is always a kind of theater ${ }^{1}$ \\ Damien Hirst \\ I doubt Amotan was the first, \\ and he was certainly not the last, \\ to hunger for such a memory theatre, \\ a great arena to house the phantasmagoria \\ that sprang from the myth-bearing mind of men $^{2}$
}

Simon Schama

Na projekt Damiena Hirsta zatytułowany Treasures from the Wreck of the Unbelievable, prezentujący fikcyjną kolekcję rzymskiego wyzwoleńca Cif Amotana $\mathrm{II}^{3}$ i opowiadający równie fantazyjną historię jej odnalezienia w wodach Oceanu Indyjskiego, składa się szereg elementów. Najważniejszy z nich to wystawa obiektów ze wspomnianego zbioru, prezentowana od 9 kwietnia do 3 grudnia 2017 roku w należących do Fundacji Pinault dwóch weneckich galeriach - Punta della Dogana oraz Palazzo Grassi ${ }^{4}$. Realizacja dzieł, zapewne od początku tworzonych z myślą o tych konkretnych obiektach ekspozycyjnych, trwała dziewięć lat (2008-2017). Historyczne budowle, w których

${ }^{1}$ D. Hirst, A. Haden-Guest, Interview, 23 listopada 2008, dostępny w internecie: $<$ https://www.interviewmagazine.com/culture/damien-hirst> [dostęp: 25 marca 2020].

2 S. Schama, Inventory, w: D. Hirst et al., Treasures from the Wreck of the Unbelievable, London 2017, s. 23.

3 Anagram od słów I am a fiction - ta wersja imienia rzymskiego wyzwoleńca nie występuje w stanowiącym część projektu filmie, gdzie jest on określany po prostu jako Amotan albo wyjątkowo jako Aulus Kalidiusz Amotan, zgodnie z rzymską tradycją potrójnego imiennictwa.

${ }^{4}$ D. Hirst, "Treasures from the Wreck of the Unbelievable”, 9 kwietnia - 3 grudnia 2017, Palazzo Grassi i Punta della Dogana, Wenecja, kurator Elena Geuna. 
mieszczą się galerie Pinaulta, oferowały nie tylko odpowiednio dużo przestrzeni (ok. $\left.5000 \mathrm{~m}^{2}\right)$, ale też atrakcyjną wizualnie i treściowo scenografię, a ich dzieje zostały wprzęgnięte $\mathrm{w}$ artystyczną narrację ${ }^{5}$. Wystawiono w nich blisko 200 rzeźb w różnej skali, liczących od kilkunastu centymetrów do kilku metrów, a w jednym - prawdziwie gargantuicznym - przypadku nawet kilkanaście metrów długości/wysokości. To ostatnie dzieło, Demon with a Bowl, wykonano z żywicy epoksydowej, gdyż brązowy oryginał był zbyt ciężki i trudny w transporcie, by można było go umieścić w dziedzińcu historycznego budynku Palazzo Grassi na niestabilnym weneckim gruncie ${ }^{6}$.

Wystawie towarzyszyły przewodniki w formie drukowanej i dźwiękowej ${ }^{7}$ oraz trzy wydawnictwa albumowe. Pierwsze $z$ nich to bogato ilustrowany katalog, zawierający - poza licznymi zdjęciami dzieł i sal wystawienniczych szereg esejów wprowadzających czytelnika w koncept ekspozycji ${ }^{8}$. Drugie to zespół spektakularnych podwodnych zdjęć z prac na fikcyjnym wraku statku „Apistos”, który miał niegdyś należeć do Amotana (il. 1). Trzecie to dwutomowa publikacja, upodobniona edytorsko do katalogów zbiorów artystycznych z przełomu XIX i XX wieku, zawierająca reprodukcje stu rysunków stylizowanych na szesnasto- i siedemnastowieczne oraz ich „krytyczne” omówienie $^{10}$. Na wewnętrznych stronach jej okładek znalazła się lista stu rysunków, zatytułowana: „A History of the World in a Hundred Objects”"11. Choć

${ }^{5}$ E. Geuna, The Coral Diver, w: Hirst et al., Treasures from the Wreck..., s. 10.

${ }^{6}$ Hirst et al., Treasures from the Wreck..., s. 381-382.

7 Treasures from the Wreck of the Unbelievable. Damien Hirst, Palazzo Grassi 2017, dostępne w internecie: < https://www.palazzograssi.it/en/exhibitions/past/damien-hirst-atpalazzo-grassi-and-punta-della-dogana-in-2017-1/\#guide> [dostęp: 11 stycznia 2019].

${ }^{8}$ Hirst et al., Treasures from the Wreck..., s. 5-27; wśród autorów znalazła się Elena Geuna, kuratorka wystawy, Martin Bethenod, dyrektor weneckich obiektów Fundacji Pinault, François Pinault, jej właściciel, Henri Loyrette, historyk sztuki i były dyrektor Luwru, Simon Schama, historyk oraz popularyzator dziejów nauki i sztuki, a także Franck Goddio, archeolog i dyrektor francuskich wykopalisk podwodnych w Aleksandrii.

9 D. Hirst, The Undersea Salvage Operation: Treasures from the Wreck of the Unbelievable, fot. C. Gerigk, S. Russell, London 2017, non vidi.

${ }_{10}$ D. Hirst, A. Corry, Treasures from the Wreck of Unbelievable: One Hundred Drawings, London 2017; niektóre z nich były wystawione w jednej z sal Palazzo Grassi, zob. Hirst et al., Treasures from the Wreck..., s. 284-315, 331-333.

${ }^{11}$ Wskazuje to, że ważnym źródłem inspiracji dla Hirsta był multimedialny projekt byłego dyrektora British Museum, Neila MacGregora, na który składała się niezmiernie popularna seria audycji radiowych na kanale BBC4 i towarzysząca jej książka - N. MacGregor, A History of the World in 100 Objects, London 2010. Kilka obiektów omawianych przez MacGregora zostało wykorzystanych przez Hirsta jako wzory dla jego rzeźb i rysunków, o czym wprost wspomniała kurator wystawy Elena Geuna: „One of the sources of inspira- 


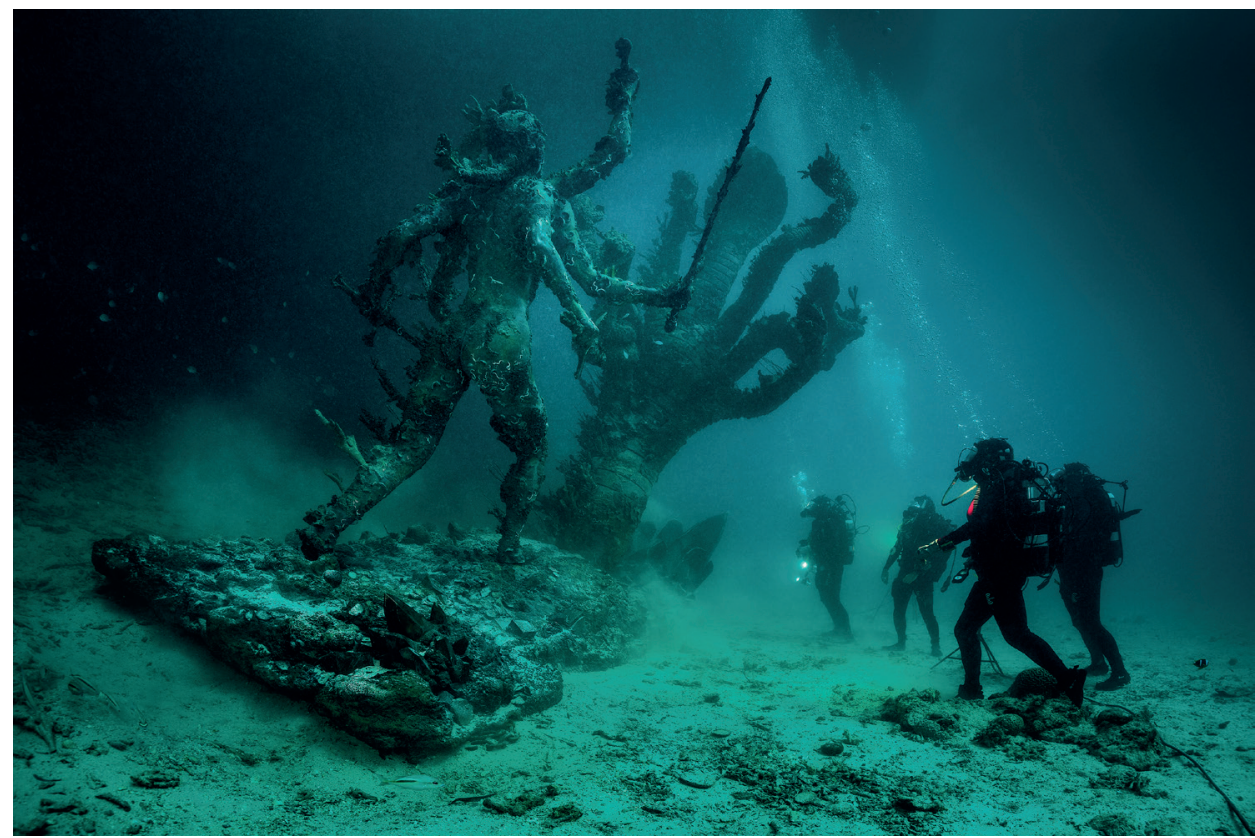

1. Damien Hirst, Hydra and Kali Discovered by Four Divers, fot. Christoph Gerigk, (C) Damien Hirst and Science Ltd., wszelkie prawa zastrzeżone, DACS/Artimage 2020, img. ref. SCI-DH-4727

wszystkie te elementy stanowią integralne części projektu, to ekskluzywność niektórych publikacji, z powodu ich ograniczonego nakładu oraz wysokich cen, sprawia, że mają charakter drugorzędny. Owszem, rozwijają i dopełniają kluczowe wątki artystycznego przedsięwzięcia, ale ich znajomość dla zrozumienia całości nie jest konieczna, choć niewątpliwie przydatna.

Dużo istotniejszą jego częścią jest fabularyzowany film pseudodokumentalny $^{12}$, stanowiący dopełnienie i rozwinięcie weneckiej wystawy. Został on udostępniony globalnie za pośrednictwem medialnej platformy interneto-

tion for the exhibition is the collection of the British Museum, in London, where the Ife heads are displayed. An Ife head from the British Museum collection has also been included in the famous book, A History of the World in 100 Objects by the former museum director Neil MacGregor", zob. P. Parke, Damien Hirst accused of copying African art at Venice Biennale, CNN2017, 11 maja, dostępnywinternecie: <https://edition.cnn.com/2017/05/10/ africa/damien-hirst-appropriation-venice-biennale> [dostęp: 3 kwietnia 2020].

12 Treasures from the Wreck of the Unbelievable, reż. S. Hobkinson, 2017; określany jako "mockumentary”, zob. Treasures from the Wreck of the Unbelievable (2017), "IMDb”, dostępny w internecie: <https://www.imdb.com/title/tt6980988/> [dostęp: 21 marca 2020]. 
wej Netflix krótko po zakończeniu ekspozycji - 1 stycznia 2018 roku. Wybór tego kanału dystrybucji, niejako w odpowiedzi na ograniczony w czasie i przestrzeni dostęp do wystawy oraz elitarność towarzyszących jej wydawnictw, stanowił bezprecedensowy zabieg Hirsta na polu egalitaryzacji sztuki współczesnej ${ }^{13}$. Artystę interesowało nie tylko jak najszersze udostępnienie jego projektu, ale też uczynienie tego w formie cyfrowej, w korespondencji $z$ jednym $z$ najważniejszych wniosków płynących $z$ jego przedsięwzięcia, że najmniej narażony na zgubny wpływ czasu jest obiekt czysto wirtualny, o ile zapewnić mu odpowiednią liczbę nośników ${ }^{14}$. Film zrealizowano rękoma doświadczonych fachowców ${ }^{15}$, stosując różne techniki zdjęciowe i rozwiązania montażowe, $\mathrm{w}$ formalno-treściowym powiązaniu $\mathrm{z}$ wydarzeniami na ekranie, odgrywanymi przez zawodowych aktorów oraz amatorów ${ }^{16}$. Dokument w części został nakręcony równocześnie z przygotowaniami do wystawy, podczas kosztownej i trudnej pod względem logistycznym operacji, w trakcie której przetransportowano niektóre obiekty z Europy do wschodniej Afryki, a pozostałe wykonano na miejscu ${ }^{17}$. Tam zostały zatopione, po czym je wydobyto w odpowiednio zainscenizowanym procesie podwodnej eksploracji i przewie-

${ }^{13}$ Według rzeczniczki artysty (a formalnie Science Ltd.), to sam Hirst zdecydował, że "Netflix was the right platform to share it with the world [podkr. - W.B.]”, cyt. za: J. Halperin, Damien Hirst Created a Fake Documentary About His Fake Venice Show-and Now You Can See It on Netflix, „Artnet News” 2019, 5 stycznia, dostępny w internecie: $<$ https://news.artnet.com/art-world/damien-hirst-created-fake-documentary-veniceshow-can-see-netflix-1192922> [dostęp: 21 marca 2020].

14 „The film is something Damien wanted people to be able to come across in years to come, which explores the backstory of the project", cyt. za: J. Halperin, Damien Hirst Created...

${ }^{15}$ Reżyser Sam Hobkinson jest uznanym twórcą filmów dokumentalnych, w tym miniserialu telewizyjnego Venice, zob. IMDb, dostępny w internecie: < https://www.imdb. com/name/nm0387700/?ref_=tt_ov_dr> [dostęp: 26 marca 2020]; podobnie Tim Cragg, autor zdjęć, ma ogromne doświadczenie w kręceniu filmów dokumentalnych, przyrodniczych oraz poświęconych sztuce i archeologii, przy których współpracował m.in. z Damianem Hirstem oraz Simonem Schamą, zob. IMDb, dostępny w internecie: < https://www. imdb.com/name/nm1145108/?ref_=fn_al_nm_1> [dostęp: 26 marca 2020].

16 Amatorzy występują pod własnymi imionami i nazwiskami, a aktorzy zachowują swoje imiona, ale nazwiska im zmieniono.

${ }^{17}$ Wprawdzie szczegóły realizacji projektu są objęte tajemnicą, ale można się domyślać po datach zdjęć Christopha Griegka, wykorzystanych do fotosów umieszczonych na wystawie, że prace na Oceanie Indyjskim odbywały się na przestrzeni co najmniej dwóch lat, zob. Hirst et al., Treasures from the Wreck..., s. 330. Narracja filmowa koresponduje z tym datowaniem, pokazując, że „wykopaliska” trwały przez dwa sezony. W trakcie pierwszego wydobyto mniejsze rzeźby (ich zdjęcia są datowane na rok 2015), a drugiego - te najbardziej monumentalne (ich fotografie opisano jako zrobione w roku 2016). 
ziono drogą morską z powrotem. Świadczy to o tym, jak ogromną wage artysta przywiązywał do stworzenia przekonującej i atrakcyjnej wizualnie oprawy swojego projektu, będąc świadom, że może to zapewnić jedynie nakręcenie niemal całego materiału na żywo, przy minimalnym użyciu komputerowych efektów specjalnych. Poza przedstawieniem odpowiednio udramatyzowanej i sfabularyzowanej historii badań film zawiera liczne wypowiedzi Hirsta na temat głównych wątków jego artystycznego przedsięwzięcia, często w formie komentarzy na temat tego, co dzieje się na ekranie. Widz ogląda twórcę mówiącego bezpośrednio do kamery lub słyszy jego głos z tzw. offu w trakcie przerywników w głównej narracji, ukazujących przywiezienie dzieł do Wenecji, później ich rozmieszczenie na ekspozycji, a na końcu przestrzenie galerii wypełnione zwiedzającymi. Obraz filmowy i komentarze pozwoliły artyście nie tylko przedstawić swoje dzieła masowemu widzowi, ale też zobrazować, jak integralnie były powiązane z przestrzenią obu galerii, zarówno kompozycyjnie, jak i semantycznie. $Z$ tego powodu część zdjęć musiała zostać zrealizowana już w trakcie wystawy, odpowiednią ilość czasu zajął również montaż i udźwiękowienie. To zapewne w dużej mierze zadecydowało, że premiera filmu odbyła się po zamknięciu ekspozycji.

Przedsięwzięcie Hirsta jest niezmiernie złożone, nie tylko ze względu na jego multimedialność, ale także wielowarstwowość. To oczywiście gra konwencjami, w swej przewrotności dla jednych zwodnicza, dla innych ironiczna. To również satyra komentująca reguły rządzące rynkiem sztuki i jednocześnie cynicznie je wykorzystująca ${ }^{18}$. Jednakże, po odarciu z tych zewnętrznych warstw, w miarę zagłębiania się (dobór słów nieprzypadkowy) $\mathrm{w}$ istotę rzeczy, w widzu narasta - wbrew rozpowszechnionym sądom na temat Hirsta - odczucie obcowania z autentycznością artystycznej wypowiedzi, z autorefleksyjną i samokrytyczną analizą tego, czym jest sztuka i kim jest ten, kto ją kreuje. Realizując swój projekt, Hirst podjął próbę stworzenia wieloaspektowej narracji, mogącej budzić skojarzenia z ideą Gesamtkunstwerku. W przeszłości tego typu przedsięwzięcia realizowano na potrzeby religii czy totalitarnych systemów politycznych, co zapewniało odpowiednią treść, wolę społeczną, zasób umiejętności i środki finansowe. Brytyjski artysta-multimilioner, stawiając sobie podobne zadanie artystyczne, dysponował dwoma

${ }_{18}$ T. Morgan, Damien Hirst's Shipwreck Fantasy Sinks in Venice, „Hyperallergic” 2017, 10 sierpnia, dostępny w internecie: < https://hyperallergic.com/391158/damien-hirsttreasures-from-the-wreck-of-the-unbelievable-venice-punta-della-dogana-palazzo-grassi $>$ [dostęp: 29 marca 2020]: „Damien Hirst's «Treasures from the Wreck of the Unbelievable» is not an exhibition. It's a showroom for oligarchs". 
ostatnimi elementami - gotów był zainwestować sporą część własnej fortuny, zaangażować doświadczony zespół współpracowników oraz wykorzystać swoją bazę warsztatową ${ }^{19}$. Dawało mu to kompletną wolność artystyczną, uniezależniając go od drugiego ze wspomnianych warunków, czyli woli społecznej. Będąc wytrawnym graczem na rynku sztuki, zdawał sobie sprawę, że popyt na jego dzieła jest na tyle duży, by zminimalizować artystyczne i inwestycyjne ryzyko ${ }^{20}$. Pozostawała rzecz najtrudniejsza, czyli rozwinięcie podstawowego konceptu w sposób, który uzasadniałby zastosowanie formuły całościowego dzieła sztuki.

Hirst, świadom wciąż aktualnej społecznej i kulturowej mocy mitu, postanowił wykorzystać jego dyskurs jako bardziej prymarny i uniwersalny niż jakakolwiek doktryna religijna czy polityczna. W realiach globalnej kultury początków XXI wieku, w dużej mierze zdominowanych przez dyskurs naukowo-techniczny, ale w istotnym stopniu także przez masową konsumpcję kina, telewizji, literatury i gier komputerowych, wymagało to stworzenia multimedialnej fikcji ${ }^{21}$. Przemyślanej, wszechogarniającej i odwołującej się do uniwersaliów, ale przede wszystkim spójnej i na tyle atrakcyjnej, aby mogła zaciekawić i zainspirować współczesnego odbiorcę, zgodnie z egalitarnym pojmowaniem funkcji sztuki przez Hirsta. W tym celu postanowiono - jak wskazuje Martin Bethenod - wykorzystać reguły „dobrowolnego zawieszenia

19 Damien Hirst on his new shipwreck exhibition, BBC News, 2017, 6 kwietnia, $<$ bbc.com/news/av/entertainment-arts-39519639/damien-hirst-on-his-new-shipwreckexhibition> [dostęp: 29 marca 2020].

20 G. Calchi Novati, Staging the Wreck of the Unbelievable. Performing ideology: Imaginary surplus, alienation and anxiety, „Performance Research” 2019, 5(24), s. 25: "Suffice it to say that the works in «Treasures» range from $\$ 500,000$ to $\$ 5$ million and that several collectors had agreed in advance to purchase pieces".

${ }^{21}$ Por. M. Westfall, The White Whale, 13 listopada 2017, dostępny w internecie: < http:// gristle.com/2017/11/13/the-white-whale> [dostęp: 29 marca 2020]: „The price of admission to Hirst's exhibition is consent to a certain fantastic fiction. This is, of course, commonplace - we do it every time we open a novel, go to the movies, watch the news, or enter the voting booth". Tekst Westfalla jest jednym z nielicznych pozytywnych opracowań lub recenzji projektu Hirsta, próbujących dokonać rzetelnej jego analizy, a nie, jak czyni to większość krytyków, skomentować to banalnym „hoax", „fake”, „sigantic pack of lies” czy nieco bardziej ambitnie „post-truth”. Dla równowagi warto przytoczyć tu słowa, które wypowiedział o „Treasures...” Francesco Bonani, kurator wcześniejszej wystawy Hirsta, „Relics”: „In his bombastic, exaggerated way, Damien has created a narrative the likes of which the public has never seen. Many will call it bad taste or kitsch, but it's more than that. It's Hollywood", cyt. za: C. Vogel, Damien Hirst is Back With an Underwater Fantasy. Will Collectors Care?, „New York Times” 2017, 6 kwietnia, dostępny w internecie < nytimes.com/2017/04/06/arts/ design/damien-hirst-francois-pinault-palazzo-grassi.html> [dostęp: 29 marca 2020]. 
niewiary", sformułowane przez Samuela T. Coleridge’a na płaszczyźnie literatury ${ }^{22}$, a od ponad stu lat $\mathrm{z}$ powodzeniem wcielane $\mathrm{w}$ życie $\mathrm{w}$ filmie fabularnym $^{23}$. Kluczowym elementem strategii artystycznej stało się ich zaadaptowanie na potrzeby projektu artystycznego, z którym ludzie mieli obcować wieloma zmysłami ${ }^{24}$. Do tego celu artysta postanowił wykorzystać niezmiernie popularne dziś medium - park rozrywki ${ }^{25}$. Na źródło jego inspiracji wskazuje umieszczony na weneckiej wystawie rzeźbiarski autoportret z Myszką $\mathrm{Miki}^{26}$, wzorowany na pomniku Walta Disneya, znajdujący się w jego parku rozrywki w Anaheim w Kalifornii ${ }^{27}$. W Palazzo Grassi ustawiono obok siebie brązowe posągi Myszki Miki ${ }^{28}$ oraz Goofy'ego ${ }^{29}$, a także rzeźbiarską grupę Mowgliego i Baloo, ukazanych jak w jednym z kadrów Disneyowskiej Księgi dżungli3i . Obok pierwszego z posągów znajduje się podświetlony fotos, uka-

${ }^{22}$ M. Bethenod, Preface, w: Hirst et al., Treasures from the Wreck..., s. 7; zob. S.T. Coleridge, Biographia Literaria or Biographical Sketches of My Literary Life and Opinions, t. 2, London 1817, s. 6; zob. rozważania Jorge Borgesa na ten temat: J.L. Borges, Narrative Art and Magic, w: idem, Selected non-fictions, New York-London 1999, s. 75-82; oraz analizę tezy Coleridge'a z perspektywy krytyki dokonanej przez J.R.R. Tolkiena, zob. T.Z. Majkowski, W cieniu Białego Drzewa. Powieść fantasy w XX wieku, Kraków 2013, s. 35-37.

${ }^{23}$ Zob. A.J. Ferri, Willing Suspension of Disbelief: Poetic Faith in Film, Lanham-New York-Plymouth 2007.

${ }^{24}$ H. Loyrette, On the Name of, w: Hirst et al., Treasures from the Wreck..., s. 16, wskazuje na inspirację wierszem Chan KubiłajColeridge'a, zob. S.T. Coleridge, Poezje wybrane, tłum. Z. Kubiak, Warszawa 1987, s. 96-98, a także jego interpretacją dokonaną przez Jorge Borgesa, zob. J.L. Borges, Oscar Wilde, Kwiat Coleridge'a, Sen Coleridge'a, „Więż” 1990, 2-3, s. 118-125; por. N. Tcherepashenets, Place and displacement in the narrative worlds of Jorge Luis Borges and Julio Cortázar, New York 2008, s. 89-95; a także powieścią historyczną Gustava Flauberta, zob. G. Flaubert, Salambo, tłum W. Rogowicz, Warszawa 1978.

${ }_{25}$ Jak pokazuje przykład Disneylandu, w takiej formule można realizować nie tylko pomysły fabularne zaczerpnięte $z$ innych rodzajów twórczości, ale też kreować własne, jak to było w przypadku Piratów z Karaibów. Późniejsze losy dwóch spośród największych kompozycji Hirsta z omawianego projektu, umieszczonych w centrum najbardziej wystawnego centrum rozrywki w Las Vegas, pokazują, jak obrana przez niego strategia artystyczna jest bliska formule parku rozrywki, zob. S. Cascone, Damien Hirst's 60-Foot-Tall Demon Will Loom Over the Most Expensive, Art-Bedecked Hotel Renovation in Las Vegas's History, „Artnet News” 2019, 3 kwietnia, dostępny w internecie: <https://news.artnet.com/artworld/damien-hirst-las-vegas-hotel-demon-1507594> [dostęp: 21 marca 2020].

26 „The Collector with Friend”, Hirst et al., Treasures from the Wreck..., s. 65.

27 „Partners”, B. Gibson, 1993.

28 "Mickey", Hirst et al., Treasures from the Wreck..., s. 186.

29 "Goofy", Hirst et al., Treasures from the Wreck..., s. 189.

30 „Best Friends”, Hirst et al., Treasures from the Wreck..., s. 287; por. Jungle Book, reż. W. Reitherman, 1967, $29 \mathrm{~min}$. 
zujący unoszenie go przez nurka $z$ dna oceanu ${ }^{31}$. Podobne ujęcie pełni istotną rolę w zakończeniu filmu, wyznaczając moment, kiedy następuje kres „dobrowolnego zawieszenia niewiary"32. Poza Disneyem wśród źródeł inspiracji znalazły się inne produkty Fabryki Snów, od klasy A do C, literatura awanturnicza i podróżnicza, romantyczna poezja, produkty przemysłu zabawkarskiego, filmy przyrodnicze, ale przede wszystkim tradycje mitologiczne, religijne i artystyczne kultur $z$ różnych czasów i miejsc. Z tego wszystkiego powstał niezmiernie eklektyczny zbiór, spojony nie tylko osobowością jego fikcyjnego twórcy Amotana, alter ego Hirsta ${ }^{33}$, ale też programem treściowym, poruszającym tak istotne dla ludzkiej egzystencji kwestie życia i śmierci, natury i sztuki, prawdy i fikcji, mitu i historii.

Jak sugeruje już sam tytuł projektu, głównym konstytuującym go elementem jest fantazja artysty. Nie stanowi ona jednak celu samego w sobie, ale paradoksalnie, jest skutkiem ukierunkowania refleksji twórcy w stronę namacalnej rzeczywistości ${ }^{34}$. Hirst koresponduje na wielu płaszczyznach z jednym z najważniejszych współczesnych trendów intelektualnych, czyli $z$ nowym materializmem ${ }^{35}$, ale jednocześnie odbiega od najbardziej idealistycznych i programowych propozycji Jane Bennett i Grahama Harmana ${ }^{36}$. Nie interesuje go bowiem polityczna agenda tych autorów, pozbawiony jest też złudzeń odnośnie do możliwości powrotu do premodernistycznego postrzegania świata ${ }^{37}$. W równym stopniu co oni skupia się na istocie rzeczy, ale nie czyni tego, wychodząc $z$ perspektywy teoretycznej, tylko opierając się na praktycznych i zaangażowanych doświadczeniach artysty i kolekcjonera.

${ }^{31}$ Hirst et al., Treasures from the Wreck..., s. 281.

32 „To Do the Impossible”, Hirst, Corry, Treasures from the Wreck..., s. 143 (rysunek Myszki Miki z adnotacją na karcie: „It's fun to do the impossible” i drugą, wykonaną odmiennym charakterem pisma: „laughing figure”).

33 Według samego artysty, Amotan był kimś więcej, postacią prawdziwie uniwersalną: „It's me, it's Pinault, it's Walt Disney, it's anyone who has a vision”, cyt. za: Vogel, Damien Hirst is Back...; albo, jak pisze Schama (Inventory, s. 23), był to jeden z ludzi „unafraid to make themselves ridiculous as the abandon themselves to the delirium of obsession".

${ }^{34}$ T. Sparrow, The end of phenomenology: Metaphysics and the new realism, Edinburgh 2014, s. 20.

35 G. Harman, Weird realism: Lovecraft and philosophy, Alresford 2012, s. 51.

${ }^{36} \mathrm{~J}$. Bennett, The enchantment of modern life: Attachments, crossings, and ethics, Princeton 2001, s. 12; G. Harman, Tool-being: Heidegger and the metaphysics of objects, Chicago, IL, 2002, s. 238.

37 B. Boysen, The embarrassment of being human: A critique of new materialism and object-oriented ontology, „Orbis Litterarum” 2018, 73, s. 229-231. 
Skutkiem tego jest postrzeganie i rozumienie rzeczy w sposób dynamiczny, we wzajemnej zależności z bytami i siłami w stosunku do nich zewnętrznymi. Zbliża go to do perspektywy tzw. symetrycznego podejścia, postulowanej przez Brunona Latoura ${ }^{38}$ i rozwijanej na polu archeologii, szczególnie przez Bjørnara Olsena i Christophera Witmore'a ${ }^{39}$. Warto zaznaczyć w tym miejscu, że kwestia interakcji człowieka z rzeczami zajmuje Hirsta od dziesięcioleci. Można wręcz uznać, że przez cały ten czas stanowiła jeden z centralnych wątków jego twórczości, obok zagadnień śmierci, rozkładu, prawdy i religii. W projekcie „Treasures...” następuje synteza wszystkich tych elementów, zapoczątkowana refleksją na temat „śmierci” rzeczy, w tym również dzieł sztuki, w wywiadzie udzielonym Hansowi Obristowi w roku 200740. Jego centralnym wątkiem uczyniono motyw transformacji, będącej efektem działania czasu, zapośredniczonego przez siły natury, ale również przez człowieka. Artysta nie zadowala się jedynie świadomością następowania tych procesów i ich śledzeniem, ale pogodziwszy się z ich nieuchronnością i uznawszy uwidaczniającą się w nich entropię za uniwersalną zasadę wszechświata, stara się je zrozumieć i naśladować ${ }^{41}$.

Przyjęcie takiej perspektywy niejako automatycznie wymusiło wplecenie tego wątku w opowieść, mającą na celu stworzenie ułudy historyczności postaci Amotana i jego kolekcji za pomocą różnego rodzaju fikcyjnych źródeł. Obiekty na ekspozycji zostały rozmieszczone w ten sposób, aby obcujący z nimi widz choć w części zaznajomił się z osnutą wokół nich narracją, nawet nie dysponując przewodnikiem i nie czytając metryczek. Zwiedzający nie mógł przeoczyć umieszczonych w kluczowych miejscach galerii podświetlonych fotosów i wideoinstalacji (il. 1) ${ }^{42}$ czy zajmującego środek jednej z sal wystawowych modelu statku rzymskiego wyzwoleńca ${ }^{43}$. Pochodzące

${ }^{38}$ B. Latour, Reassembling the Social: An Introduction to Actor-Network Theory, Oxford 2005, s. 76.

39 B. Olsen, In Defense of Things. Archaeology and the Ontology of Objects, Lanham, MD, 2010, s. 135; C.I. Witmore, Symmetrical archaeology: Excerpts of a manifesto, „World Archaeology" 2007, 4(39), s. 547.

${ }^{40}$ H.U. Obrist, D. Hirst, An Interview, 2007, dostępny w internecie: < http://www. damienhirst.com/texts/20071/feb--huo > [dostęp: 27 marca 2020]: „So I suppose if things can come to life then they can also die. You can create an artwork, and it comes to life, but then maybe 500 years later it dies. I've never really thought about that. It's a weird thought; a good thought".

${ }^{41}$ Ibidem: „I mean, every day you have to deal with your own mortality, so a good way of doing that without too much fear is to deal with the mortality of an object".

${ }^{42}$ Hirst et al., Treasures from the Wreck..., s. 262-281.

43 Ibidem, s. 12. 
z jego wraku obiekty - nie tylko dzieła sztuki, ale też przedmioty codziennego użytku - zaopatrzono w ślady zniszczeń podobne do tych, jakie zostawia natura czy też destruktywne działania człowieka (il. 3). Te zabiegi, mogące się kojarzyć z procederem falsyfikacji na potrzeby rynku podrabianych antyków, dla Hirsta same w sobie stały się niezmiernie istotnym działaniem artystycznym. Wykorzystał je do naśladowania natury, rozumianego nie jako imitacja wyglądu rzeczy, ale w arystotelesowskim postrzeganiu sztuki (techne), jako podążanie za tym, jak działa physis, autonomicznie manifestująca się w obiektach przyrody siła sprawcza ${ }^{44}$ (a także, jak w tym wypadku, destrukcyina). We współczesnej refleksji nad naturą rzeczy panuje przekonanie, że w głównej mierze definiuje je materialność, a czasowość, choć dostrzegana, jest spychana na dalszy plan jako nadmiernie poddana modernistycznemu rozumieniu temporalności ${ }^{45}$. Według Hirsta to niewłaściwe myślenie, bo pomniejsza albo wręcz neguje znaczenie procesu historycznego, dotykającego tak samo ludzi, jak i nieludzi, choć w różnym stopniu i tempie. Ujmuje to dynamiki zarówno jednym, jak i drugim, a więc deprecjonuje to, kim/czym naprawdę są. Aby móc traktować rzeczy równoważnie z ludźmi, należy podkreślić ich zmienność w czasie, dynamiczną metamorficzność, $z$ tego względu, że cykl ich życia był, jest i będzie nierównomierny, w zależności od wytrzymałości materiałów, jakości wykonania, intensywności i umiejętności użytkowników. Doskonale to uświadamia samo doświadczenie codzienności, ale też praktyka archeologiczna, podobnie jak historyczno-artystyczna, szczególnie realizowana na poziomie znawstwa, kolekcjonerstwa i muzealnictwa.

Archeologia stała się więc kluczowym elementem „Treasures...” nie tylko z tego powodu, że zajmuje się wydobyciem i dokumentacją artefaktów $z$ minionych epok, ale też dlatego, że śledzi same mechanizmy procesów depozycji i podepozycji ${ }^{46}$. Jej celem jest określenie sposobów, w jakie rzeczy trafiły do środowiska, w którym zostały odnalezione, i jakie zjawiska na nie oddziaływały, doprowadzając do stanu zaobserwowanego w momencie odkrycia. Ale dla Hirsta archeologia to nie tylko dyscyplina badająca przeszłość rzeczy, ale - zgodnie z dynamicznym ich postrzeganiem - także narzę-

${ }^{44}$ Arystoteles, Fizyka, 199a11-19; zob. S. Barnett, Rhetoric's Nonmodern Constitution: Techne, Phusis, and the Production of Hybrids, w: Thinking with Bruno Latour in Rhetoric and Composition, red. P. Lynch, N. Rivers, Carbondale, IL, 2014, s. 90-94.

45 Olsen, In Defense of Things, s. 136-146.

46 A.M. Pollard, Measuring the Passage of Time: Achievements and Challenges in Archaeological Dating, w: The Oxford Handbook of Archaeology, red. B. Cunliffe, C. Gosden, R.A. Joyce, Oxford-New York 2009, s. 123-139; B. Olsen et al., Archaeology: The Discipline of Things, Berkeley-Los Angeles-London 2012, s. 160. 
dzie ich kreacji, piszące kolejny rozdział w historii ich metamorfoz. Z tego powodu nadał części wystawy charakter muzealny, stosując względem swoich dzieł różnorakie strategie restauratorsko-konserwatorsko-ekspozycyjne, a w filmie dokonując wiwisekcji archeologicznego procesu badawczego. Miało to na celu wskazanie elementów wpływających na to, że efektów ich pracy nie można uznać za obiektywną prawdę naukową. Najważniejszą z szeregu przyczyn jest to, co podkreślał w katalogowym eseju Frank Goddio, główny naukowy konsultant projektu, pisząc, iż odkrywanie wraku jest przede wszystkim jego tworzeniem ${ }^{47}$.

Dla Hirsta jest to oczywiście jedna z wielu zalet kontekstualizacji kolekcji Amotana jako pochodzącej ze statku zatopionego w wodach Oceanu Indyjskiego, gdyż otwiera to szereg tropów interpretacyjnych. Lokalizacja wraku w tym miejscu w istotny sposób nawiązuje do koncepcji „oceanic site”, sformułowanej przez Roberta Smithsona w rozdziale jego tekstu pod jakże tutaj znaczącym tytułem The Wreck of Former Boundaries ${ }^{48}$. Jest to konsekwencją faktu, że nawet tak rozległe i znaczeniowo naładowane obiekty jak Punta della Dogana i Palazzo Grassi okazały się niewystarczające, aby pomieścić ambicje Hirsta. Dopiero ocean, dzięki swojej wielkości, tajemniczości i rozbuchanej naturze, zapewnił odpowiednią oprawę - można by powiedzieć, w sposób tak bliski brytyjskiemu twórcy - gablotę dla ekspozycji jego dzieł ${ }^{49}$. Co więcej, jego wody, niczym formaldehyd wypełniający szklane pojemniki wcześniejszych dzieł artysty, stają się częścią opowieści oraz narzędziem estetyzacji, w tym wypadku oferującym tak ulubione przez niego bogactwo kolorów. To dlatego tak istotnym elementem wystawy są wspomniane już fotosy i wideoinstalacje, ukazujące rzeźby i nurków, którzy przy nich pracują lub je podziwiają (il. 1) s0 $^{50}$. $\mathrm{Z}$ tego samego powodu wiele obiektów zostało przestrzenno-wizualnie po-

${ }^{47}$ F. Goddio, Discovering a Shipwreck, w: D. Hirst et al., Treasures from the Wreck..., s. 24, 26, używa francuskiego określenia inventeur une épave, świadomie wygrywając jego wieloznaczność, bo można je odczytywać nie tylko jako metaforę procesu badawczego, inwentaryzacji, ale też jako odniesienie do artystycznej kreacji „Apistosa” przez Hirsta.

${ }^{48}$ R. Smithson, A Sedimentation of the Mind: Earth Projects, "Artforum” 1968, 1(7), s. 90: „Yet, if art is art it must have limits. How can one contain this «oceanic» site? I have developed the Non-Site, which in a physical way contains the disruption of the site. The container is in a sense a fragment itself, something that could be called a three-dimensional map. Without appeal to "gestalts» or "anti-form», it actually exists as a fragment of a greater framentation. It is a three-dimensional perspective that has broken. Away from the whole, while containing the lack of its own containment. There are no mysteries in these vestiges, no traces of an end or a beginning".

49 D. Hirst, G. Burn, On The Way To Work, London 2001, s. 155: „Everything's a box”.

${ }^{50}$ Hirst et al., Treasures from the Wreck..., s. 268-269. 
wiązanych z oknami galerii, otwierającymi się na wody weneckich kanałów. Co jednak ważniejsze, ocean wypełnia niemal całość filmu, stanowiąc wręcz jego istotę; widoczny nad i pod powierzchnią, a w kluczowych momentach wydobywania rzeźb - w trakcie przekraczania tej granicy. Jednocześnie jednak ocean jest antyformaldehydem, gdyż o ile zadaniem tego drugiego jest powstrzymanie zepsucia, o tyle ten pierwszy, co nieustannie w ramach projektu się podkreśla, jest siłą niszczycielską, odciskającą na obiektach piętno upływającego czasu.

Większość rzeźb wchodzących w skład projektu wykonano z brązu - zarówno posągi naturalnej wielkości, jak i masywne grupy, zajmujące rozległe przestrzenie najniższego poziomu Punta della Dogana. Artysta na przestrzeni ostatnich dwudziestu lat sięgał dość często po ten materiał ze względu na jego właściwości plastyczne, strukturalną wytrzymałość oraz masę, względnie niewielką w stosunku do rozmiaru posągów. W mniejszym stopniu zainteresowany jest barwą i fakturą tego metalu, stąd rozpowszechniona w jego twórczości tendencja do patynowania rzeźb lub ich polichromowania za pomocą odpowiednio spreparowanych lakierów ${ }^{51}$. Opracowanie części figur wystawionych w Wenecji z użyciem spektakularnych barw w istotnej mierze kreuje kluczowy wątek koncepcji artysty, czyli iluzję pokrycia ich warstwą stworzeń morskich, korali i gąbek (il. 3). Miało to budować przeświadczenie widza o pochodzeniu rzeźb ze starożytnego wraku, podobnie jak imitacja uszkodzeń mechanicznych, najczęściej występujących w obiektach odnalezionych przez archeologów, czyli fragmentacja, zarysowania powierzchni i pokrywająca je patyna. Drugim pod względem częstotliwości wykorzystania surowcem jest marmur, najczęściej biały z Karrary, ale w pojedynczych przypadkach również różowy oraz czarny ${ }^{52}$. Okazyjnie sięgano po inne rodzaje kamienia i minerały, takie jak czarny granit, lazuryt, kryształ górski czy malachit, czasami eksplorując ich symboliczne konotacje. Stosując kamień, artysta jest bliższy prawdzie materiału, podkreślając jego naturalną barwę i wykorzystując plastyczne właściwości dla osiągnięcia gładkiej faktury i delikatnego opracowania szczegółów. Posągi wykonane z kamienia, choć często poddane fragmentacji, generalnie są pozbawione imitacji morskich organizmów albo pokryto je nimi

51 Technikę tę po raz pierwszy Hirst zastosował w monumentalnym posągu Hymn z roku 1999, zob. Hirst, Burn, On The Way..., s. 147.

${ }^{52}$ Hirst et al., Treasures from the Wreck..., s. 66-67, 352 („Reclining Woman”, różowy marmur); s. 124-125, 370-371 („Dead Woman”, czarny marmur). 
w dużo mniejszym stopniu niż te odlane $z$ brązu, przypuszczalnie na skutek ograniczeń materii i techniki rzeźbiarskiej ${ }^{53}$.

Specyficzną i kluczową dla treściowego programu Hirsta grupę stanowią statuetki, sprawiające wrażenie wykonanych ze złota, choć opisy drobnym drukiem wskazują, iż w rzeczywistości zrobiono je z pozłacanego srebra lub stopu tych metali. Pozbawione są plastyczno-malarskich imitacji morskich narostów; w niektórych wypadkach stworzono jedynie efekt mechanicznych uszkodzeń. Ustawiono je w odpowiednio zaciemnionej sali muzealnej, aby móc za pomocą sztucznego, punktowego oświetlenia mocno uwypuklić cechy tego surowca, które są szczególnie cenione przez artystę, czyli gładkość i blask ${ }^{54}$. Obiekty rozstawiono wokół centralnie zlokalizowanego dysku z płaskorzeźbionym, frontalnym wyobrażeniem twarzy, ilustrującego solarny aspekt Apolla ${ }^{55}$, (re)kreując planowane rozmieszczenie przedmiotów z kolekcji Amotana w ufundowanej przez niego świątyni tego boga ${ }^{56}$. Widziana $z$ tej perspektywy, kolekcja przekonanego o istnieniu mitycznych stworzeń i czczącego idole wyzwoleńca nie jest już tylko skutkiem jego estetycznych wyborów, ale też wyrazem jego wiary. Pokazuje, że powstanie i zniszczenie zbioru nie jest zależne tylko od jednostek czy bezosobowych sił przyrody, ale też od procesów historycznych, takich jak starcia systemów światopoglądowych. Z tej perspektywy zatonięcie "Apistosa" (to greckie słowo w tradycji biblijnej oznacza niewiernego lub heretyka) można zaprezentować jako karę, którą poganin Amotan miał ponieść z rąk chrześcijańskiego Boga, a nawet więcej - jako alegorię końca pogańskiego świata ${ }^{57}$.

Jedną z grup rzeźbiarskich, marmurowe Pair of Slaves Bound for Execu$t_{i o n}{ }^{58}$, opracowano w sposób naśladujący uszkodzenia mechaniczne będące skutkiem ostrzału $z$ broni palnej - jak ilustruje to załączony w katalogu foto-

${ }^{3} \mathrm{~Np}$. „Unknown pharaoh”, Hirst et al., Treasures from the Wreck..., s. 51 (biały marmur bez narostów); s. 209 (niebieski granit i złoto, pokryty przedstawieniami muszelek z białego agatu); s. 306 (rysunek ukazujący popiersie z adnotacją „The Unknown Pharaoh, 1501 (marmo e oro)"); Hirst, Corry, Treasures from the Wreck of Unbelievable, s. 103 (inny szkic tego samego posągu).

${ }^{54}$ Efekty luministyczne odmiennej natury, w postaci mocnych refleksów italskiego słońca, osiągnięto, eksponując złoconą rzeźbę, przedstawiającą czaszkę jednorożca, na tarasie Punto della Dogana. Zdominowała ona jednocześnie główną oś widokową z wnętrza budowli na wody Canale Grande, zob. Hirst et al., Treasures from the Wreck..., s. 122-123, 369.

55 Hirst et al., Treasures from the Wreck..., s. 99 (t), s. 364-365 (ekspozycja); Hirst, Corry, Treasures from the Wreck..., s. 119.

56 Treasures..., reż. S. Hobkinson, 57-59 min.

57 Tak według Loyrette, On the Name..., s. 13, miały o tym mówić fikcyine fragmenty tekstów przypisywanych pisarzom chrześcijańskim, w tym Orygenesowi.

${ }^{58}$ Hirst et al., Treasures from the Wreck..., s. 131. 
montaż - przez niemieckich żołnierzy w czasach drugiej wojny światowej ${ }^{59}$. W tym wypadku ze względów oczywistych nie opisuje się tej rzeźby jako obiektu wydobytego $z$ wraku, ale późniejszą realizację, stworzoną na podstawie antycznych opisów obiektów z kolekcji Amotana ${ }^{60}$. Artysta w tym dziele realizuje dwie kluczowe dla projektu koncepcje. Po pierwsze, pokazuje, że niszczycielskie dla dzieł sztuki działanie czasu może być skutkiem ludzkiego wandalizmu czy raczej zaplanowanego barbarzyństwa. Po drugie, eksploruje frapującą go ideę jak antyczne ekphrasis, czyli literacka forma opisu niezachowanych czy wręcz nigdy nieistniejących dzieł sztuki, inspirowała ich (re)kreacje w późniejszych epokach. Ten wątek jest dyskutowany przez Loyrette'a ${ }^{61}$, ale przede wszystkim realizowany w rysunkach, stylizowanych na wczesnonowożytne i odpowiednio postarzonych i w niektórych wypadkach zaopatrzonych w szesnastowieczne daty, z których część została wyeksponowana w jednej z sal Palazzo Grassi. Ukazano na nich większość rzeźb z wystawy, a także szereg obiektów, które nigdy się na niej nie znalazły. Niektóre ze szkiców określono jako ilustracje powstałe na podstawie wspomnianych opisów, inne jako studia przygotowawcze do - zainspirowanych nimi, ale nigdy niepowstałych - dzieł sztuki. Wzorcowym przykładem wykorzystania motywu ekphrasis w „Treasures..." jest złota, płaskorzeźbiona tarcza Achillesa, którą Amotan miał zamówić jako ilustrację homeryckiego opisu, prezentowana na wystawie razem z ukazującym ją pseudoszesnastowiecznym rysunkiem ${ }^{62}$. Warto podkreślić, że w tym i szeregu innych wypadków obcujemy z paradoksem - trudno ocenić, na ile zamierzonym, a na ile będącym skutkiem zagubienia w spiętrzeniu fikcji - kiedy rysunki ukazują rzeźby nie w takim stanie, w jakim miały trafić do ładowni „Apistosa", ale w takim, w jakim były w momencie odkrycia jego wraku ${ }^{63}$.

59 „Marble Slaves Used for Target Practice”, Hirst et al., Treasures from the Wreck..., s. 130.

${ }^{60} \mathrm{Na}$ ekspozycji obok tej grupy ustawiono jej wariant (a w zasadzie to „oryginał" pochodzący z wraku), zatytułowany Children of the Dead King, Hirst et al., Treasures from the Wreck..., s. 129 (brąz bez uszkodzeń mechanicznych, ale pokryty narostami); s. 372-373 (obie grupy w jednym ujęciu); Hirst, Corry, Treasures from the Wreck..., s. 61.

${ }^{61}$ Loyrette, On the Name..., s. 16, cytuje kluczowe dla zrozumienia całości projektu Hirsta słowa B. Cassin, „Ekphrasis”: from Word to Word, w: Dictionary of the Untranslatables: A Philosophical Lexicon, red. eadem, Princeton-Oxford 2015, s. 205: „With exphrasis, we [...] find ourselves in the world of art and artifice, ruled by and following the performative, effective power of speech that has been from truth and falsehood, as it sets out not to say what it sees, but to make it seen what it says".

${ }^{62}$ Hirst et al., Treasures from the Wreck..., s. 117, 366 („The Shield of Achilles”); s. 285 (rysunek Lo scudo d'Achille (oro)); Hirst, Corry, Treasures from the Wreck..., s. 83.

${ }^{63}$ Trzeba podkreślić, że stosunkowo rzadko pokazuje się na rysunkach rzeźby pokryte narostami morskimi, ale niemal bez wyjątku przedstawia się ich uszkodzenia mechaniczne. 
Istotnym elementem strategii artystycznej Hirsta było stworzenie wielu serii rzeźb z wykorzystaniem odmiennych materiałów i w różnej skali. Co więcej, część obiektów zaprezentowano w stanie, w jakim miały zostać odkryte, a obok ustawiono rzeźby poddane konserwacji oraz ich współcześnie wykonane rekonstrukcje ${ }^{64}$. W ten sposób zagadnienie multiplikacji, frapujące artystę od lat, zostało użyte do stworzenia iluzji wystawy będącej pokłosiem badań wykopaliskowych. Posłużyło to do zobrazowania niszczycielskiego wpływu czasu i czynnika ludzkiego na przedmioty $z$ dawnych czasów, jednocześnie zwiększając pulę dzieł, które miały zostać sprzedane po zakończeniu wystawy. Idąc dalej w kierunku kreacji przestrzeni quasi-muzealnej, w Palazzo Grassi umieszczono szereg gablot ${ }^{65}$, wypełnionych replikami i przetworzeniami wytworów różnych kultur z mniej lub bardziej odległej przeszłości - broni, narzędzi, naczyń, biżuterii i płacideł ${ }^{66}$. $\mathrm{W}$ połączeniu $z$ bogactwem form i różnorodnością ich pochodzenia budzi to skojarzenia ze sposobem prezentacji ludzkich wytworów, wykorzystywa-

${ }^{64}$ Geuna, The Coral Diver, s. 10; por. Vogel, Damien Hirst is Back...: „In each edition there are three sculptures: what Mr. Hirst describes as "Coral», meaning the work created too look like its "original» encrusted state from the deep; a "Treasure», the artwork seemingly restored by conservators for display; and the "Copy», which purports to be a modern museum reproduction of the original". W tym ostatnim przypadku widoczne jest nawiązanie do muzealnictwa przełomu XIX i XX wieku, pozostającego w estetyce całości i w przypadku sztuki klasycznej, zdominowanego przez tzw. Kopienkritik, czyli (re)konstruowanie greckich oryginałów z fragmentów rzymskich kopii, z wykorzystaniem metody filologicznej, zob. A. Furtwängler, Meisterwerke der griechischen Plastik. Kunstgeschichtliche Untersuchungen, t. 1-2, Leipzig 1893; por. R. Bianchi Bandinelli, Archeologia klasyczna jako historia sztuki, tłum. i posłowie W. Dobrowolski, Warszawa 1988, s. 70-72, il. viii, x-xi, xiii.

${ }^{65}$ Hirst et al., Treasures from the Wreck..., s. 220-243, 248-259, 343.

${ }^{66}$ Palazzo Grassi w minionych dekadach gościło kilka wystaw archeologicznych, które Bethenod (Preface, s. 7) określa mianem legendarnych ze względu na ich poziom naukowy, ale też spektakularność oraz różnorodność prezentowanych na nich kultur, zob. m.in. S. Moscati, The Phoenicians, Venezia 1988; S. Moscati, E. Arslan, D. Vitali, The Celts: The Origins of Europe, New York 1991; P. Schmidt, M. De La Garza, E. Nalda, I Maya, Milano 1998; M. Torelli, The Etruscans, Milano 2001; E.S. Greene, J. Leidwanger, Damien Hirst's Tale of Shipwreck and Salvaged Treasure, „American Journal of Archaeology Online" 2017, 13 grudnia, dostępny w internecie: <https://www.ajaonline. org/sites/default/files/1221\%20Greene_0.pdf> [dostęp: 12 marca 2019], s. 9, podnoszą krytykę, że Hirst i Pinault wraz ze współpracownikami rozmyślnie wykorzystali skojarzenia z muzealną historią budowli dla podbicia cen dzieł z projektu „Treasures...”. Jednak dzięki strategii promocyjnej akcji marketingowej Hirsta, znaczący kolekcjonerzy byli doskonale świadomi, z czym będą mieli do czynienia, czy wręcz dokonali zakupów na długo przedtem, zanim rzeźby trafiły do weneckiej galerii, zob. Vogel, Damien Hirst is Back... 
nym w muzeach etnograficznych. Artysta poszedł krok dalej w grze konwencjami ekspozycyjnymi, nawiązując również do sposobu prezentacji zbiorów przyrodniczych. Realizował w ten sposób istotną dla jego kolekcjonerstwa koncepcję Wunderkammery ${ }^{67}$, expressis verbis odnoszoną do działań Amotana jako alter ego Hirsta ${ }^{68}$. Podobnie jak w złotym okresie tego typu zbieractwa, w weneckich galeriach znalazły się różnorakie mirabilia, na pierwszy rzut oka będące wytworami natury, ale w rzeczywistości wyprodukowane przez człowieka ${ }^{69}$. Są to rzeźbiarskie przedstawienia czaszek mastodonta ${ }^{70}$, „obrośnięte" samorodkami złota minerały ${ }^{71}$ czy wykonane z polichromowanego brązu naturalnej wielkości imitacje muszli przydaczni olbrzymiej (Tridacna gigas) ${ }^{72}$. Na wystawie umieszczono też dwie wykonane w tej samej technice naśladownictwa muszli łodzika (z rzędu Nautilida), w jednym wypadku ukazanej w całości, a w drugim rozciętej, aby zaprezentować jej spiralne wnętrze, powszechnie - choć nie do końca właściwie - budzące skojarzenia z graficzną ilustracją złotego cięcia ${ }^{73}$. Tak ważny dla narracji Hirsta wątek prawdy odniesiono tutaj do relacji natury

${ }^{67}$ D. Hirst, Wunderkammer, „damienhirst”, 2015, dostępny w internecie: < http://damienhirst.com/texts/2015/wunderkammer> [dostęp: 28 marca 2020].

${ }^{68}$ Schama (Inventory, s. 19, 22) przyrównuje Amotana do słynnych nowożytnych zbieraczy - Alfonsa d'Este, księcia Kosmy I Medyceusza oraz cesarza Rudolfa II, wykazujących podobne zainteresowania kolekcjonerskie.

${ }^{69}$ Encyklopedyczne podejście do zbieractwa było w dużej mierze zainspirowane „Historią Naturalną" Pliniusza Starszego, zob. E. Schulz, Notes on the history of collecting and of museums, w: Interpreting Objects and Collections, red. S.M. Pearce, London-New York 2003, s. 175-187; w nawiązaniu do tej tezy H. Loyrette (On the Name..., s. 15-16) prezentuje ładunek "Apistosa” jako najwcześniejszą, być może nawet mu współczesną, realizację koncepcji rzymskiego polihistora.

${ }^{70}$ Hirst et al., Treasures from the Wreck..., s. 86-88, 360 (dwa marmurowe warianty Skull of a Cyclops); s. 178 (brązowa Skull of a Cyclops); s. 303 (szkic A Cyclops Skull. Three studies); s. 296 (rysunek zatytułowany I ciclopi (dall'occhio rotondo)); Hirst, Corry, Treasures from the Wreck of Unbelievable, s. 93, rysunek z adnotacją: „Skull of the Polythemus” (sic!); zob. też s. 117 (szkic czaszki tyranozaura, zatytułowany Monster's skull).

${ }^{71}$ Hirst et al., Treasures from the Wreck..., s. 244-247; Hirst, Corry, Treasures from the Wreck..., s. 77 (niewystawiony rysunek Meteorite).

${ }^{72}$ Hirst et al., Treasures from the Wreck..., s. 41 („Extraordinarily Large Museum Specimen of Giant Clam Shell”); s. 201 („Museum Specimen of Giant Clam Shell (I)"); s. 213 („,Museum Specimen of Giant Clam Shell (II)").

${ }^{73}$ Hirst et al., Treasures from the Wreck..., s. 165 („Museum Specimen of Giant Nautilius Shell”); s. 190-191 („Museum Specimen of Giant Nautilius Shell (Interior Exposed)"); na temat tego rodzaju muszli i zagadnienia złotego cięcia zob. J. Sharp, Spirals and the Golden Section, „Nexus Network Journal” 2002, 1(4), s. 78-79. 
i kultury, zacierając sztucznie wyznaczone w okresie Oświecenia granice ${ }^{74}$. Medium przejścia jest oczywiście sztuka, dzięki swej mocy mimetycznej i możliwości kreowania znaczeń.

Artysta, uczyniwszy swoim podstawowym narzędziem „dobrowolne zawieszenie niewiary”, kreuje uniwersum, w którym nieustannie ścierają się prawda $z$ fikcją, jednocześnie się dopełniając. W narracyjny nawias brane są historia i geografia kulturowa, ulegając nieustannym czasowo-przestrzennym przetasowaniom. Podobnie jak w przypadku fabularnego dzieła literackiego czy filmowego, liczy się jedynie wewnętrzna spójność narracji ${ }^{75}$. Zawiesiwszy kryterium prawdy i nieprawdy, przyjmujemy, iż nic nie jest niemożliwe, co z kolei sprawia, że wszystko staje się potencjalnie możliwe. Nie chodzi tu oczywiście o oddanie się chaosowi, bo byłoby to antysztuką, czego artysta jest doskonale świadom. Zero-jedynkowe pojmowanie prawdy i fałszu również go jednak nie interesuje, bo jest domeną filozofii i nauk ścisłych. Wykorzystuje więc pierwotną formę zapanowania nad chaosem, czyli mityczną opowieść, z niemal nieskończonym bogactwem jej możliwych odniesień i modyfikacji. Równie ważny jak treść jest więc sposób jej prezentacji, odwołujący się do prymarnych, a więc egalitarnych i uniwersalnych, elementów kultury i sztuki. Kombinuje w tym celu nawiązania do pogańskich korzeni tradycji europejskiej ze strukturalnie jej bliskimi - ale odległymi w czasie i przestrzeni - elementami kultur egzotycznych. Dotyczy to w równym stopniu formy oraz treści, co zrozumiałe, zważywszy na wtórne i sztuczne rozróżnienie tych dwóch aspektów mitu. Hirst, używając form i reguł mitycznej opowieści, podejmuje tematy centralne dla każdej ludzkiej kultury, dotykające istoty egzystencji człowieka: życie i śmierć, czas i przestrzeń, część i całość, ludzie i bogowie. Oczywiście wątki te pojawiały się we wcześniejszych dziełach artysty, szczególnie w pierwszej dekadzie XXI wieku, tam jednak dominowały teologiczne $\mathrm{i} /$ lub artystyczne odniesienia do katolicyzmu ${ }^{76}$. Tutaj nacisk został położony na podstawową zasadę, którą rządzi się mit, czyli metamorfozę. Dlatego przedstawia się opowieść o Amotanie i o jego skarbach jako ewoluującą na przestrzeni stuleci i rozbudowywaną o nowe wątki. Geuna opisuje to jako

${ }^{74}$ B. Latour, We Have Never Been Modern, Cambridge, MA, 1993; S. Choat, Science, Agency and Ontology: A Historical-Materialist Response to New Materialism, „Political Studies" 2018, 4(66), s. 1037-1039.

75 Schama, Inventory, s. 22.

76 Wystawy: D. Hirst, „Romance in the Age of Uncertainity”, 9 września - 18 grudnia 2003; White Cube, Londyn; D. Hirst, „New Religion”, 13 października - 19 listopada 2005, Paul Stolper Gallery, Londyn. 
proces naturalny i nieunikniony, w którym co prawda coś zostaje utracone, ale na tym miejscu pojawia się coś nowego ${ }^{77}$. Opowieść prezentowana w ten sposób przypomina rzeźby spoczywające na dnie, które choć ulegają postępującemu zniszczeniu, to jednocześnie stają się czymś nowym, wzbogaconym o bajecznie wybujały i barwny element natury w postaci narostów stworzeń ${ }^{78}$.

Najbardziej istotnym przewodnikiem po labiryncie mitologicznych transformacji pozostają dla Hirsta epickie poematy Homera i Hezjoda, ale przede wszystkim Metamorfozy Owidiusza. Z tej poetyckiej tradycji artysta zaczerpnął inspirację dla tłumu istot, których wyobrażeniami zapełnił pomieszczenia weneckich galerii. Najważniejsza z nich to Meduza, zredukowana do najbardziej istotnego fragmentu, łączącego to, co ludzkie i zwierzęce, czyli głowy $z$ wężowymi włosami ${ }^{79}$. Hirst postrzega tę postać w kontekście relacji natury i sztuki oraz życia i śmierci, subtelnie wygrywając jej ambiwalentny status ofiary przemiany, która sama również dysponuje mocą metamorfozy. Nie tylko transformuje żywych w posągi siłą swego petryfikującego spojrzenia, ale też w momencie swojej śmierci powołuje do istnienia Pegaza i Chryzoara ${ }^{80}$, a później z kropel jej krwi rodzą się węże w piaskach Sahary ${ }^{81}$, a wyrzucone na brzeg wodorosty transformują w korale ${ }^{82}$. W swoim postrzeganiu Gorgony artysta jest niewątpliwie zainspirowany badaniami Stephena Wilka, kładącego mocny nacisk na jej związki z różnymi sferami mitycznego świata ${ }^{83}$. Podkreśla jej obecność na nocnym niebie w gwiazdozbiorze Perseusza ${ }^{84}$, ale przede wszystkim w Hadesie, podziemnym królestwie śmierci, gdzie spotkaniem $z$ jej duchem był straszony Odyseusz ${ }^{85}$, a na walkę $z$ nim szykował się

77 Geuna, The Coral Diver, s. 10.

78 Podobnie pisze o metamorfozie opowieści S.R. Wilk, Medusa: Solving the Mystery of the Gorgon, Oxford 2000, s. 8: „The core of the narrative remains the same, but elements accrete, like barnacles growing on an ship, until the entire story has undergone a sea change, covered with new and strange details".

79 „The Severed Head of Medusa” (cztery warianty rzeźby i dwa rysunki), Hirst et al., Treasures from the Wreck..., s. 76, 106-107, 118-119, 198-199, 298; Hirst, Corry, Treasures from the Wreck..., s. 107.

80 Hezjod, Teogonia, 280.

81 Apolloniusz, Wyprawa Argonautów IV.1515; Owidiusz, Metamorfozy IV.770; Lukan, Farsalia IX.820.

82 Owidiusz, Metamorfozy IV.745-750; nawiązuje do tego wprost kustoszka wystawy, Geuna, The Coral Driver, s. 10.

${ }^{83}$ Wilk, Medusa.

${ }^{84}$ Ibidem, s. 116-125.

${ }^{85}$ Homer, Odyseja, XI.635-636; zob. A. Karanika, The End of the Nekyia: Odysseus, Heracles, and the Gorgon in the Underworld, „Arethusa” 2011, 1(44), s. 1-27. 
Herakles $^{86}$. Dla amerykańskiego autora uniwersalnym źródłem dla wariacji na temat monstrualnej, ukazywanej frontalnie twarzy, napotykanych na obszarze niemal całego globu, jest wizualne doświadczenie różnych kultur z rozkładającą się głową trupa ${ }^{87}$. Ta wizja doskonale daje się odnieść do nieustannie powracającej w twórczości Hirsta obsesji śmierci i jej manifestacji w ciele ludzkim i zwierzęcym, przede wszystkim w partii głowy. Poza wspomnianymi wyobrażeniami głowy Meduzy, w projekcie „Treasures...", widoczne jest to w „Death's Head" ${ }^{88}$, Dead Man ${ }^{89}$ i The Skull Beneath the Skin ${ }^{90}$. W zestawie dzieł artysty znalazły się również zaczerpnięte z mitów balijskich upiorne maski Rangda oraz jej przeciwnika Baranga (marmurowe Pair of Masks)191, a także nawiązująca do sztuki azteckiej półtwarz, półczaszka w centrum $\mathrm{Ca}$ lendar Stone ${ }^{92}$, wszystkie wspomniane przez Wilka jako kulturowe analogie dla greckiego Gorgoneionu ${ }^{93}$.

Mimo iż te i wiele innych obiektów z wystawy stylem oraz treścią nawiązuje do kultur z perspektywy europejskiej egzotycznych, to wciąż w niej dominują - co zrozumiałe w kontekście pochodzenia „znaleziska” - wielopłaszczyznowe odniesienia do kultury, sztuki i literatury starożytnych ludów śródziemnomorskich. Są to jednak bardziej zapożyczenia treściowe niż formalne, gdyż ujęcia tematów centralnych dla antyku są niemal bez wyjątku przefiltrowane przez nawiązania nowożytne, nowoczesne i współczesne. Wizje głowy Meduzy mają więcej wspólnego z obrazem Caravaggia znajdującym

86 Apollodoros, Biblioteka, II.5.12.13-17; S. Dova, Greek Heroes in and out of Hades, Lanham-Plymouth 2012, s. 80-84.

87 Wilk, Medusa, s. 190: „The Gorgoneion is terrible because it shows us the transformation of a human being into Death...".

${ }^{88}$ Hirst et al., Treasures from the Wreck..., s. 147; Hirst, Corry, Treasures from the Wreck..., s. 101, choć rzeźba jest wykonana z czarnego granitu, to na rysunku znajduje się też adnotacja w języku włoskim: piombo. To rozmyślny zabieg, jako iż ołów w świecie antycznym kojarzył się z zaświatami i dlatego używano go do wytwarzania tabliczek lub figurek $z$ wyrytymi magicznymi rysunkami i formułami, zakopywanych w ziemi w celu rzucenia klątwy, zob. F. Graf, Magic in the Ancient World, Cambridge, MA, 1997, s. $118-174$.

89 Hirst, Corry, Treasures from the Wreck..., s. 193 (tylko rysunek).

${ }^{90}$ Hirst et al., Treasures from the Wreck..., s. 159; Hirst, Corry, Treasures from the Wreck..., s. 41.

${ }^{11}$ Hirst et al., Treasures from the Wreck..., s. 55, 307; Hirst, Corry, Treasures from the Wreck..., s. 133.

${ }^{92}$ Hirst et al., Treasures from the Wreck..., s. 34; Hirst, Corry, Treasures from the Wreck..., s. 17.

93 Wilk, Medusa, s. 55-57, 72-73. 
się w Galerii Uffizi we Florencji ${ }^{94}$ czy kreacją legendarnego hollywoodzkiego specjalisty od efektów specjalnych Raya Harryhausena ${ }^{95}$ niż z jakimkolwiek antycznym jej przedstawieniem ${ }^{96}$. Zwielokrotnione torsy rzeźbiarskie, określane jako „Grecian Nudes"97 albo „Antique Torsos"98, wbrew wyrażanym przez niektórych badaczy opiniom nie są wzorowane na posągu Afrodyty Knidyjskiej ${ }^{99}$, ale stanowią monumentalizację korpusów lalki Barbie ${ }^{100}$, a ich podobieństwo do dedalickich aktów z Krety jest raczej przypadkowe ${ }^{101}$. Najbliższa antycznej rzeźbie greckiej pod względem formalnym i kompozycyjnym jest brązowa statua Hermafrodyty ${ }^{102}$, która ukazuje postać kobiecą z męskimi genitaliami, a dodatkowo, w interesujący z perspektywy dwupłciowości sposób, kombinuje dwie konwencjonalne pozy. Lewa strona figury realizuje wspo-

94 A.W.G. Posèq, Caravaggio and the Antique, "Artibus et Historiae” 1990, 11(21), s. $157-159$.

95 Clash of the Titans, reż. D. Davis, 1981, 82-89 min.

96 Warto tu wspomnieć, że jedno z czterech rzeźbiarskich przedstawień Meduzy - to wykonane z pozłacanego srebra - w latach 2018-2019 było wystawione w galerii sztuki grecko-rzymskiej Ashmolean Museum w Oksfordzie, w zestawieniu z terakotową płaskorzeźbą z ok. 540 roku p.n.e., zob. D. Hirst, „The Severed Head of Medusa”, Ashmolean Museum, 2018-2019, dostępny w internecie: < https://www.ashmolean.org/event/damien-hirst-medusa > [dostęp: 29 marca 2020].

97 Hirst et al., Treasures from the Wreck..., s. 42-44, 295. Znaczace jest zastosowanie na określenie tych aktów archaicznego przymiotnika Grecian zamiast obecnie rozpowszechnionego Greek, zob. Grecian, „Cambridge Dictionary”, dostępny w internecie: $<$ https://dictionary.cambridge.org/pl/dictionary/english/grecian> [dostęp: 25 marca 2020]. To niewątpliwie ironiczne użycie pojęcia, które w XIX i w początkach XX wieku kojarzyło się z uznawaną za wyższą sztuką i kulturą greckiego antyku, na określenie ikony współczesnej kultury masowej, wywodzącej się w prostej linii od epatującej seksualnością laleczki dla dorosłych, Lilli, zob. J. Latson. The Barbie Doll's Not-for-Kids Origins, „Time” 2015, 9 marca, dostępny w internecie: < https://time.com/3731483/barbie-history> [dostęp: 29 marca 2020]; na „renesansowym” rysunku jedna z rzeźb jest jednak opisana jako „Greek figure", zob. Hirst, Corry, Treasures from the Wreck..., s. 15.

${ }_{98}$ Hirst et al., Treasures from the Wreck..., s. 46-47.

99 Greene, Leidwanger, Damien Hirst's Tale..., s. 5.

100 Hirst et al., Treasures from the Wreck... s. 43, 295; Hirst, Corry, Treasures from the Wreck..., s. 15, na co wprost wskazuje napis „Mattel. Made in China” z tyłu jednego z nich, a pośrednio wykonanie tej rzeźby z różowego marmuru, dzięki czemu przypomina lalkę Barbie nie tylko kształtem, ale też kolorem.

101 Por. A. Stewart, Greek Sculpture: an Exploration, t. 2, Plates, New Haven-London 1990, ryc. 32, 503.

${ }^{102}$ Hirst et al., Treasures from the Wreck..., s. 160-162; Hirst, Corry, Treasures from the Wreck..., s. 73. 
mniany typ przedstawieniowy Afrodyty dłuta Praksytelesa ${ }^{103}$, stosowany wyłącznie w wizerunkach kobiecych, podczas gdy po prawej zastosowano układ ciała zastrzeżony dla hellenistycznych i rzymskich wyobrażeń zwycięskich wodzów i władców ${ }^{104}$.

Ciekawa w projekcie Hirsta jest eliminacja tak ważnych - nie tylko dla kultur antycznych - postaci herosów, mimo iż znalazły się w nim przedstawienia scen mitologicznych, w których brali udział. Zrealizowane w nadnaturalnej skali, zdominowały przyziemie Punta Della Dogana, stanowiąc jedne z pierwszych obiektów, z którymi obcował widz zwiedzający wystawę. Mają formę grup rzeźbiarskich, w których co prawda pobrzmiewają echa monumentalnej plastyki hellenistycznej, ale głównym źródłem inspiracji zdają się być filmowe wizje mitologii greckiej. Ilustrując najbardziej dramatyczne momenty opowieści - gwałt Minotaura na młodej dziewczynie ${ }^{105}$ czy atak morskiego potwora na Andromedę ${ }^{106}$ - wprzęgnięto widza w bezpośrednią relację z tym, co zostało przedstawione. Można przypuszczać, że w ten sposób artysta odniósł się do dydaktycznego i moralizatorskiego aspektu wielu mitów $z$ całego świata, zadając oglądającemu pytanie, czy gotów jest zadziałać tak, jak zrobili to bohaterowie dawnych opowieści, czy też woli pozostać pasywnym świadkiem ${ }^{107}$. Sztuka grecka stanowiła jedno z podstawowych narzędzi kształtujących samokontrolę (sophrosyne) nad zwierzęcą częścią ludzkiej natury, do czego nawiązano w rzeźbiarskiej ilustracji rytuału przejścia ateńskich dziewcząt, odbywającego się w świątyni Artemidy w Brauron ${ }^{108}$. Innym istotnym wątkiem obecnym w twórczości starożytnych artystów była odwieczna walka sił porządku z chaosem, której uniwersalny charakter podkreślono, przeciwstawiając sobie postaci z różnych kręgów kulturowych, czyli boginię Kali i Hydrę (il. 1) $)^{109}$.

103 A. Ajootian, Praxiteles, w: Personal Styles in Greek Sculpture, red. O. Palagia, J.J. Pollitt, Cambridge 1996, s. 98-103.

104 J.J. Pollitt, Art in the Hellenistic Age, Cambridge 2006, s. 72-76.

105 Hirst et al., Treasures from the Wreck..., s. 141 (The Minotaur); s. 286 (szkic zatytułowany Minotauro (granito)); Hirst, Corry, Treasures from the Wreck..., s. 49 (inna wersja rysunku pod tytułem The Beast Man).

106 Andromeda and the Sea Monster, Hirst et al., Treasures from the Wreck..., S. $184-185$.

107 Ujmując to przez pryzmat tak bliskich Hirstowi popkulturowych odniesień - daje się widzowi potęgę spojrzenia po to tylko, aby zaraz mu przypomnieć, że „with great power, comes great responsibility”, por. Spiderman, reż. S. Raimi, 2002, 36 min.

108 "Warrior and the Bear", Hirst et al., Treasures from the Wreck..., s. 37, 342 (brąz); s. 175 (srebro); s. 284 (rysunek); Hirst, Corry, Treasures from the Wreck..., s. 67.

109 „Hydra and Kali”, Hirst et al., Treasures from the Wreck..., s. 60-63, 362-363 (brąz); s. 173 (srebro); s. 298 (rysunek pod nieco zmienionym tytułem Kali and Hydra in 
Jest to jeden ze stosunkowo nielicznych wizerunków bóstw na wystawie Hirsta, i to wykonany, tak jak większość pozostałych przypadków, w drodze formalnej i/lub treściowej reinterpretacji. Kolejnym tego przykładem jest rzeźbiarska grupa z brązu ukazująca leżącego wśród rozbitych naczyń Bachusa, pojonego winem przez dwóch stojących nad nim satyrów. Choć elementy tego wyobrażenia zaczerpnięto $\mathrm{z}$ antyku, kompozycja całości wydaje się bliższa manierystycznej wizji starożytnej mitologii ${ }^{110}$. Wyjątkiem od tej reguły jest niewielka złota figurka przedstawiająca Merkurego w sposób typowy dla sztuki cesarskiego Rzymu: nagiego, w skrzydlatym kapeluszu, z merkuriuszem w lewym ręku, trzymającego w wyciągniętej prawej dłoni sakiewkę lub paterę ${ }^{111}$. Figurka została ustawiona na dość wysokiej ostrosłupowej podstawie, co zdaje się sugerować, że służyła jako obiekt prywatnego kultu, który byłby jak najbardziej na miejscu w kajucie samego Amotana. Wskazuje na to dokonana przez Loyrette'a astrologiczna interpretacja charakteru wyzwoleńca, a właściwie samego Hirsta, jako ucieleśniającego typowe cechy Bliźniąt, znaku zodiaku zdominowanego przez Merkurego właśnie ${ }^{112}$. W szeregu wypadków wyobrażeniom bogów nadano podobieństwo do współczesnych celebrytów (np. Aton o twarzy i ciele Rihanny) ${ }^{113}$ albo też kształty zaczerpnięte z popkultury, jak w przypadku mezoamerykańskich bogów, Quetzalcoatla i Huehueteotla, ukazanych jako Deceptikon i Transformer ${ }^{114}$. W pierwszym przypadku koncept boskości celebrytki jest dość banalny, za to w drugim mamy do czynienia z szukaniem podobieństw pomiędzy pozornie odległymi

Battle); Hirst, Corry, Treasures from the Wreck..., s. 55; wyobrażenie mitycznego potwora stanowi kolejny cytat $z$ twórczości Harryhausena, tym razem $z$ filmu Jason and Argonauts, reż. D. Chaffey, 1963.

110 Bacchus, Hirst et al., Treasures from the Wreck..., s. 142, 377; Hirst, Corry, Treasures from the Wreck..., s. 37.

111 Hirst et al., Treasures from the Wreck..., s. 211; Hirst, Corry, Treasures from the Wreck..., s. 181.

${ }^{112}$ Loyrette (On the Name..., s. 13-14) rozwija wątek gwiazdozbioru Disokurów/Bliźniąt jako przewodników rzymskiego wyzwoleńca i jego żeglarzy na pokładzie „Apistosa”. Podkreśla, że w antycznym pogaństwie rozpowszechnione było przekonanie, nawet wśród sceptycznie względem tradycyjnych wierzeń nastawionych umysłów, jak cesarza Hadriana, że ciała niebieskie kształtują charaktery i wpływają na ludzkie zachowanie; por. G.M. Cooper, Astrology: The Science of Signs in the Heavens, w: The Oxford Handbook to Science and Medicine in the Classical World, red. P.T. Keyser, J. Scarborough, Oxford 2018, s. 381-407.

${ }^{113}$ Hirst et al., Treasures from the Wreck..., s. 81 (Aten); s. 294 (rysunek zatytułowany The Empress. Studies); Hirst, Corry, Treasures from the Wreck..., s. 127.

114 Hirst et al., Treasures from the Wreck..., s. 109 („Quetzalcoatl”); s. 174 („Huehueteotl and Olmec Dragon"); Hirst, Corry, Treasures from the Wreck..., s. 61. 
tradycjami kulturowymi. Wizerunki te wykazują bowiem pokrewieństwo nie tylko w geometryzacji form, ale też odnośnie do charakteru i roli, jaką pełnią w odwiecznym ścieraniu się kosmicznych sił.

Nie ulega wątpliwości, że wizja podwodnych wykopalisk przedstawiona w filmie jest oparta na eseju autorstwa Francka Goddio, zamieszczonym w głównym katalogu wystawy ${ }^{115}$, który na etapie tworzenia scenariusza i realizacji został mocno sfabularyzowany. Choć w trakcie adaptacji wyeliminowano wiele naukowych aspektów narracji francuskiego autora, to jednak wciąż zdołano pokazać najistotniejsze elementy eksploracji archeologicznej zarówno pod względem organizacyjnym, jak i metodycznym ${ }^{116}$. Podwodnym badaniom towarzyszą emocje odkrywania, znane chyba każdemu adeptowi dyscypliny, które bardzo plastycznie opisuje Goddio, mający wieloletnie doświadczenie w znajdowaniu zalegających na dnie skarbów ${ }^{117}$. Wpływają one, obok odniesień do tradycji podwodnych filmów dokumentalnych ${ }^{118}$, na spo-

115 F. Goddio, Discovering a Shipwreck..., s. 24-27, opisuje przebieg postępowania badawczego archeologii podwodnej w sposób niemal podręcznikowy, por. J. Green, Maritime Archaeology: A Technical Handbook, San Diego 2004; Underwater Archaeology: The Nautical Archaeological Society Guide to Principles and Practice, red. A. Bowens, MaldenOxford 2009.

116 Hirst z pewnością nie miał zamiaru stworzenia ekranizacji podręcznika archeologii podwodnej, gdyż był w pełni świadomy, że większość widzów kojarzy ją wyłącznie z telewizyjnych dokumentów ukazujących piękne morskie pejzaże, wypełnione cudami natury, skarbami i nurkami. Trudno więc mieć wątpliwości, że nieprawidłowości i przeoczenia w odniesieniach do praktycznej wiedzy o przeszłości popełniono w sposób rozmyślny. Są na tyle zaakcentowane w filmowej narracji, że można je wręcz postrzegać jako sygnały dla uważnego widza, że obcuje z fikcyjnym obrazem.

117 Można też przypuszczać, że jako doświadczony archeolog podwodny brał udział w realizacji filmu w roli konsultanta technicznego i prawdopodobnie miał wpływ na jego stronę wizualną - tak też sądzą E.S. Greene i J. Leidwanger (Damien Hirst's..., s. 7). Podobieństwa do multimedialnych prezentacji jego własnych wykopalisk w porcie Aleksandrii są zbyt duże, by mogły być dziełem przypadku. Co więcej, oba projekty łączy osoba doskonałego fotografa podwodnego Christopha Gerigka, zob. Franck Goddio, Underwater Archaeologist, dostępny w internecie: < https://www.franckgoddio.org/projects/sunken-civilizations/alexandria.html> [dostęp: 25 marca 2020]. Por. Hirst et al., Treasures from the Wreck..., s. 334.

118 Por. The Cousteau Odyssey, seria 1, odc. 8, reż. J.-I. Cousteau, 1976 - film Hobkinsona pod tyloma względami przypomina tę produkcję, że momentami można odnieść wrażenie, że to jej remake. Bardzo podobne są schematy narracji, praca kamery, ujęcia scen eksploracji, montaż, a także sposób budowania napięcia w obliczu zbliżającej się gwałtownej burzy, zmuszającej statek badawczy do schronienia się w porcie. 
sób prowadzenia kamery. Pokazując przebieg badań, operatorzy wielokrotnie stosują dynamiczne i dwukierunkowe przejścia między szerokimi planami a zbliżeniami, zarówno w ujęciach podwodnych, jak i powietrznych. W pierwszym wypadku jest to możliwe dzięki temu, iż kamerzyści unoszą się w wodzie, a w drugim osiągnięto ten efekt dzięki zastosowaniu dronów. Z kolei wydarzenia mające miejsce na statku badawczym czy w bazie na lądzie sfilmowano $z$ ręki. Sytuuje to widza w perspektywie współuczestnika i doskonale podkreśla emocje towarzyszące szczególnie ciekawym odkryciom czy też sporom między członkami ekipy. Na przykład po odnalezieniu pierwszych obiektów wykonanych ze złota kierownictwo w trybie nagłym zwołuje naradę we własnym gronie i zamyka się w pomieszczeniu, opuszczeniem żaluzji odcinając kamerę (i widza), dotychczas podążających za jednym z badaczy. Również z ręki, choć bardziej statycznie, w sposób typowy dla telewizyjnego reportażu nakręcono wypowiedzi lokalnych rybaków na temat prowadzonych w pobliżu badań. Fakt, iż pierwsze odkrycia były dziełem amatorów, podkreślono przez zastosowanie odpowiadającej temu wizualnej formuły w postaci rozchwianych, nieumiejętnie skadrowanych i zmontowanych ujęć. Z kolei komentarze Hirsta i głównych postaci fabularnych skierowane bezpośrednio do kamery nakręcono, ustawiwszy ją na statywie, zaś ujęcia wnętrz galerii i bibliotek/archiwów zdynamizowano płynnym jej prowadzeniem na wózku.

Na ekranie można zobaczyć nie tylko sposób, w jaki zabytki są pozyskiwane $z$ dna morza, ale też zapoznać się z innymi problemami, z którymi zmagają się archeolodzy w różnych stadiach projektu. Najważniejsze z nich są to trudności w pozyskaniu środków do prowadzenia badań, których rozwiązanie następuje przez wprowadzenie w świat przedstawiony postaci Hirsta jako „zaangażowanego sponsora, który wykazywał zainteresowanie, miał pieniądze i był gotów ponieść ryzyko". Artysta mówi wprost do kamery, rozmywając granicę między poziomami narracji, że postanowił się zaangażować w realizację badań z powodu swojej fascynacji morzem jako niezgłębionym i tajemniczym żywiołem, zainspirowany oglądanymi w dzieciństwie filmami o poszukiwaniu podwodnych skarbów ${ }^{119}$. Kreuje się na dobroczyńcę kultury i nauki, polemizując ze sposobem pokazywania go w mediach przez pryzmat skandali $i$ wysokich cen uzyskiwanych na aukcjach jego dzieł ${ }^{120}$. Hirstowi jednak chodzi o coś więcej, gdyż w miarę oglądania, jasne staje się z jego wypowiedzi, a także słów włożonych w usta uczestników fikcyjnej ekspedycji, że żywotnie

119 Ibidem, 11-12 min.

${ }^{120}$ Ibidem, $10 \mathrm{~min}$, zilustrowano to w filmie przez dynamicznie zmontowany zestaw ujęć i komentarzy z telewizyjnych wiadomości. 
frapują go kwestie, którymi zajmują się badacze przeszłości. To zainteresowanie manifestuje się na obu poziomach narracji, podobnie jak sponsoring artysty czy też przypomnienie w filmie uczestnikom ekspedycji - i jednocześnie odgrywającym ich aktorom i naturszczykom - że obowiązuje ich klauzula poufności ${ }^{121}$.

W filmie odniesiono się także do delikatnych kwestii zachowania środowiska naturalnego oraz poszanowania lokalnego dziedzictwa kulturowego ${ }^{122}$, a obsady dokonano zgodnie z regułami politycznej poprawności. Wśród fikcyjnych postaci naukowców, odgrywanych przez aktorów, znajdują się kierujący ekipą biały Brytyjczyk, afroamerykańska profesor historii sztuki, niemiecki doktorant politechniki, polski archeolog i holenderski religioznawca. Obok nich w filmie zabierają głos prawdziwi specjaliści oraz występują liczni naturszczycy o różnych kolorach skóry - przedstawiciele lokalnych służb konserwatorskich, nurkowie, strażnicy i rybacy. W ten sposób udało się pokazać prace zespołu i załogi statku-bazy w sposób naturalny i przekonujący. Przy okazji, na zasadzie narracji równoległej, twórcy dokumentu pozwalają widzowi wczuć się w realia życia na wielkim transportowcu pływającym po wodach Oceanu Indyjskiego w epoce Cesarstwa Rzymskiego, obrazując, jak mogła wyglądać i funkcjonować wieloetniczna i wielojęzyczna obsada "Apistosa”"123. $\mathrm{Z}$ tej perspektywy pokazano wydobyte $\mathrm{z}$ wraku tzw. zabytki masowe, głównie metalowe przedmioty życia codziennego - proste w formie naczynia i rzeczy osobiste członków załogi. O tym, iż byli to ludzie "tacy jak my”, informuje nas przejście kamery od zgromadzonych na pokładzie znalezisk metalowych naczyń do stalowego garnka na kuchence w kambuzie, w którym kuk przygotowuje posiłek dla członków ekspedycji ${ }^{124}$. Można w tym zabiegu dostrzec nie tylko odniesienie do powszechnie stosowanej współcześnie konwencji popularyzatorskiej archeologii, ale także próbę ukazania rzeczy z uwzględnieniem bliskich Hirstowi postulatów nowego materializmu.

121 Ibidem, $43 \mathrm{~min}$.

122 Poszukiwania były prowadzone przy wschodnich brzegach Afryki przez podmiot zewnętrzny, więc kluczowa z perspektywy postkolonialnej była aprobata ekologów i lokalnych służb konserwatorskich. W filmie, zmontowanym już po rozpoczęciu wystawy, te kwestie zostały mocniej zaznaczone, zapewne w odpowiedzi na zarzuty skierowane przeciwko artyście i jego współpracownikom, zob. Parke, Damien Hirst accused of copying...; por. Greene, Leidwanger, Damien Hirst's Tale..., s. 11, gdzie twierdzi się, iż: „In marrying art to outdated views of archaeology, Hirst reifies an exploitative approach to heritage and an appropriation of others' past for a new elite".

123 Goddio, Discovering a Shipwreck, s. 25.

124 Treasures..., reż. S. Hobkinson, $23 \mathrm{~min}$. 
Pierwszym etapem filmowej wizji badań archeologicznych jest odkrycie stanowiska, które następuje dzięki znalezisku złotej figurki małpki125, dokonanemu przez rybaków żyjących u wschodnich brzegów Afryki ${ }^{126}$. To wręcz stereotypowe zawiązanie akcji, przywodzące na myśl okoliczności odkrycia brązowych rzeźb z antycznych wraków na Morzu Śródziemnym, na które przypadkowo natrafiali poławiacze gąbek lub rybacy (il. 4) ${ }^{127}$. Być może nawiązano w ten sposób do podobnych znalezisk, dokonywanych przez ludzi morza już w starożytności (il. 2) ${ }^{128}$. Kluczowe dla wizji Hirsta jest, że świat nauki, reprezentowany przez fikcyjną postać Petera Weissa, dowiaduje się o odkryciu posążku z amatorskiego filmu, obejrzanego przez niego w internecie. Postać doktoranta niemieckiej politechniki ma dramatyzować opowieść o odkrywaniu przeszłości i uosabiać jej romantyczny, marzycielski element. Weiss jest nowym Heinrichem Schliemannem, porzucającym niedające mu satysfakcji zajęcie po to, by udowodnić prawdziwość opowieści, powszechnie uważanej za legendarną i niewartą wiary ${ }^{129}$. Jego awanturnicze poszukiwania z udziałem afrykańskich nurków owocują odnalezieniem „klasycznej rzeźby,

125 The Sadness, Hirst et al., Treasures from the Wreck..., s. 105; Hirst, Corry, Treasures from the Wreck..., s. 5.

126 Treasures..., reż. S. Hobkinson, 6-7 min.

127 Koło Antikythery - P. Kabbadias, The Recent Finds off Cythera, „Journal of Hellenic Studies" 1901, 21, s. 205; A. Tourtas, The discovery of the Antikythera shipwreck: The social aspect, Southampton 2014, s. 15-19 [University of Southampton, praca magisterska]; Mahdia - A. Merlin, Statues de bronze trouvées près de Mahdia, „Comptes rendus des séances de l'Académie des Inscriptions et Belles-Lettres” 1908, 4(52), s. 245; Artemizjon - S. Hemingway, The Horse and Jockey From Artemision: A Bronze Equestrian Monument of the Hellenistic Period, Berkeley-Los Angeles-London 2004, s. 35-37; Maratonu P.G. Calligas, Statue of a Young Athlete, w: Mind and Body: Athletic Contests in Ancient Greece, red. O. Tzachou-Alexandri, Athens 1989, s. 179-180; oraz tzw. brąz Getty’ego, z Adriatyku - J. Frel, The Getty Bronze, Los Angeles 1978, s. 3; C.C. Mattusch, The Victorious Youth, Los Angeles 1997, s. 20; zob. też J. Felch, R. Frammolino, Chasing Aphrodite: The Hunt for Looted Antiquities at the World's Richest Museum, Boston-New York 2011, s. 9-14, o kryminalnych aspektach odkrycia i sprzedaży tej rzeźby.

${ }^{128}$ O takim przypadku pisał Pauzaniasz, Opisanie Grecji, X.19.3; por. D. Freedberg, Potęga wizerunków, tłum. E. Klekot, Kraków 2005, s. 35; a inny przedstawiono na płaskorzeźbie z czasów Cesarstwa Rzymskiego, odnalezionej w sanktuarium Herkulesa w Ostii, zob. G. Becatti, Il culto di Ercole ad Ostia, „Bullettino della Commissione Archeologica Comunale di Roma" 1938-1939, 67, s. 40; D.R. Boin, A Hall for Hercules at Ostia and a Farewell to the Late Antique "Pagan Revival”, „American Journal of Archaeology” 2010, 2(114), s. 259-261.

129 Por. D.A. Traill, Schliemann's “Dream of Troy”: The Making of a Legend, „Classical Journal” 1985, 1(81), s. 13-24; K. Maurer, Archeology as Spectacle: Heinrich Schliemann's Media of Excavation, „German Studies Review” 2009, 2(32), s. 303-317. 


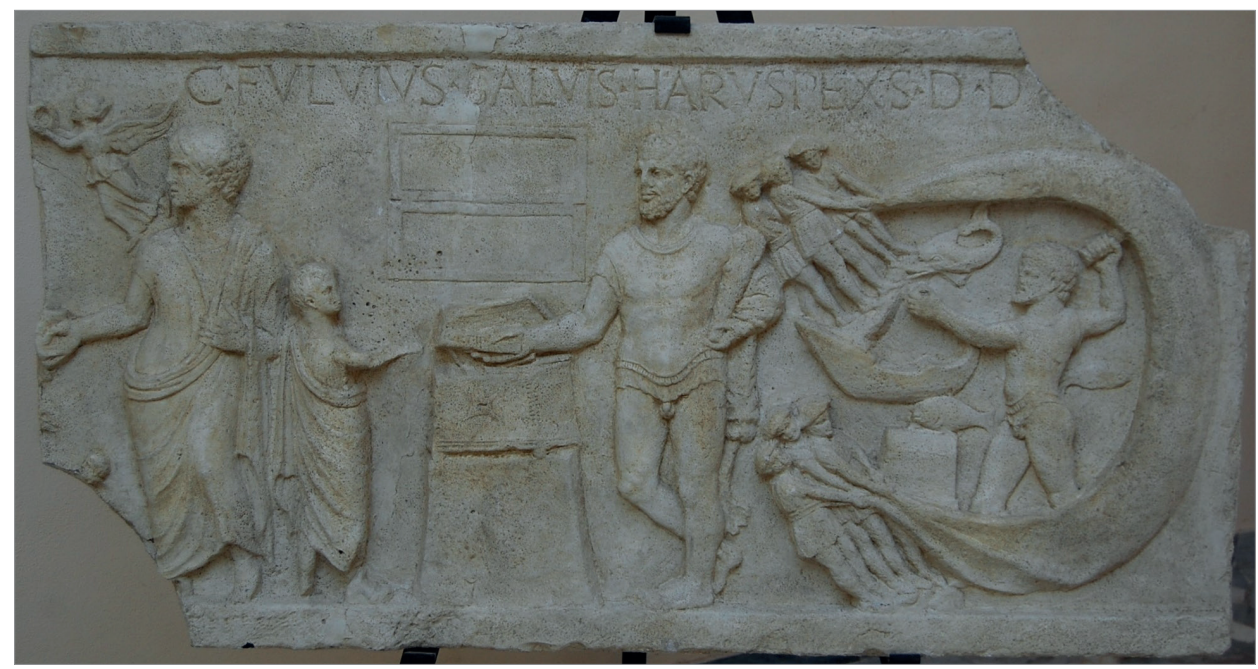

2. Płaskorzeźba wotywna przedstawiająca znalezienie posągu Herkulesa przez rybaków, z sanktuarium Herkulesa z Ostii, I w. p.n.e. (?), trawertyn, Parco Archeologico di Ostia Antica [Park Archeologiczny w Ostii], nr inw. 157

która przez długi czas spoczywała na dnie morza"130, jak określa ją z offu Andrew Lerner, fikcyjny brytyjski archeolog i późniejszy szef ekspedycji ${ }^{131}$. To badacz o skrajnie odmiennym od Weissa charakterze i nastawieniu względem przeszłości, pozytywista i mentalny spadkobierca innego z klasyków archeologii, Flindersa Petrie, pragnący zdobywać wiedzę nawet z najdrobniejszych i najpowszedniejszych zabytków ${ }^{132}$. Goddio w swoim eseju pokazuje odmienny bieg wydarzeń, w którym statuetka zaplątała się w sieci rybaków w momencie, gdy prace nad lokalizacją wraku "Apistosa" były już mocno zaawansowane. Jak podkreśla, wszystko zaczęło się w „miejscach pamięci”, czyli bibliotekach i archiwach, gdzie miano odnaleźć rysunki dzieł z kolekcji Amotana i fragmenty różnorakich dokumentów odnoszących się do katastrofy jego statku ${ }^{133}$.

W tym zestawieniu dwóch historii odkrycia widać skłonność Hirsta do nieustannego mieszania nie tylko poziomów narracji, ale też prawdy i fikcji. W jego wizji film $z$ kanału przypominającego YouTube ma podobną war-

130 „Greek Nude", Hirst et al., Treasures from the Wreck..., s. 42.

131 Treasures..., reż. S. Hobkinson, 9-10 min.

${ }^{132}$ Zob. A. Stevenson, „We Seem to be Working in the Same Line”: A.H.L.F Pitt-Rivers and W.M.F. Petrie, „Bulletin of the History of Archaeology” 2012, 1(22), s. 4-13; M.S. Drower, Flinders Petrie: A Life in Archaeology, Madison 1995.

133 Goddio, Discovering a Shipwreck, s. 24-25. 


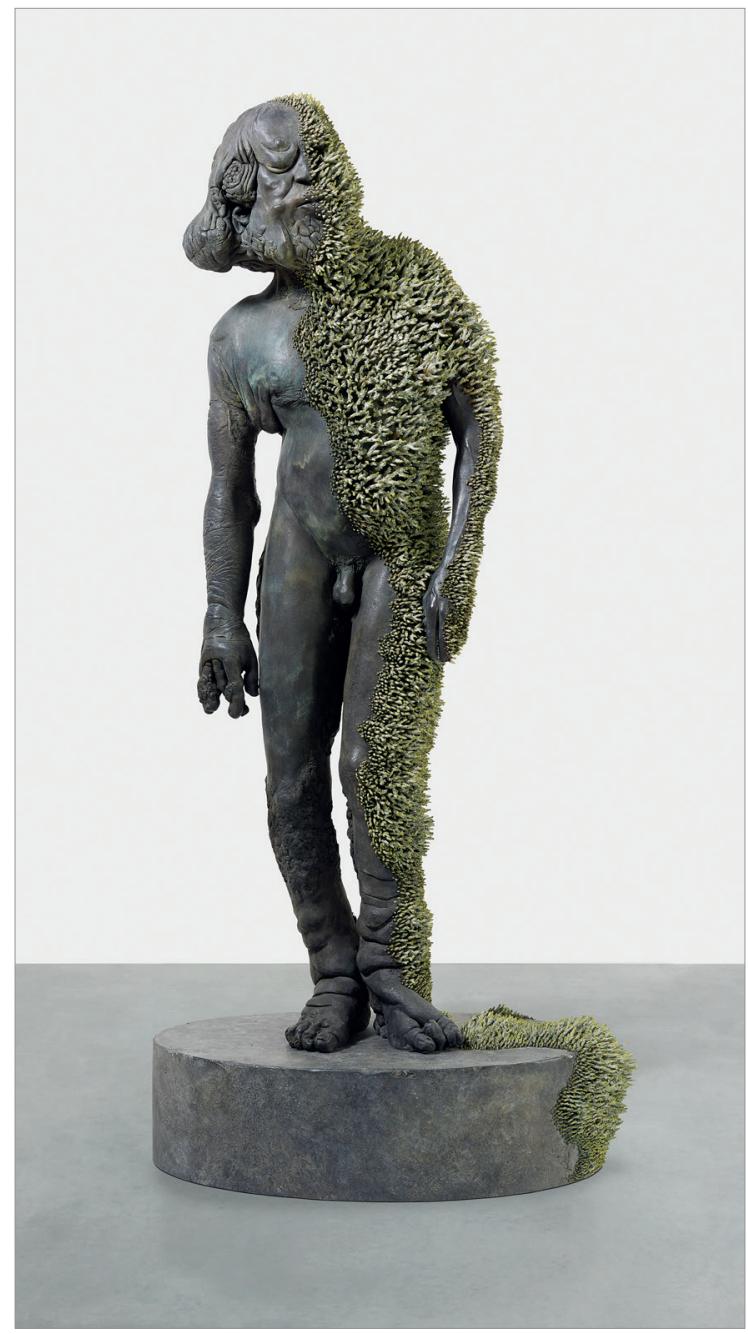

3. Damien Hirst, „Proteus”, (C) Damien Hirst and Science Ltd., wszelkie prawa zastrzeżone, DACS/Artimage 2020, img. ref. SCI-DH-4724

tość źródłową co liczące setki lat dokumenty przechowywane w archiwach. Kontynuacją tej postawy jest budowanie dramaturgii pokazanych w filmie badań wokół rywalizacji dwóch wspomnianych ekranowych osobowości. W ten sposób brytyjski twórca wprzęga stworzone przez siebie dzieła w dwutorową narrację historyczną. Pierwsza $z$ nich to artystyczna opowieść bliska antycznemu (i romantycznemu) postrzeganiu dziejopisarstwa, osnuta wokół uniwersalnych i mitycznych wątków, zilustrowanych przez formę, materię 
i treść prezentowanych rzeźb. Druga to historia rozumiana pozytywistycznie, jako naukowy proces badania i poznania procesu dziejowego, umożliwiający jego (re)konstrukcję. Pierwsza otwiera pole fantazji, co wymaga wiary, zaangażowania i zachwytu nad obiektem, druga zaś poszukuje prawdy na drodze żmudnych badań, dyscypliny i krytycznej analizy. Ta dwoistość jest obecna zarówno w opisach dzieł w przewodnikach, jak i we wszystkich - mniej lub bardziej fantazyjnych - esejach zamieszczonych w katalogu wystawy ${ }^{134}$.

Głównym źródłem inspiracji dla stworzenia koncepcji „Apistosa” jako pływającej kolekcji dzieł sztuki był jeden z najważniejszych i największych spośród tysięcy wraków spoczywających na dnie Morza Śródziemnego, odnaleziony u brzegów greckiej wyspy Antikythera ${ }^{135}$. Obok słynnego astronomicznego mechanizmu, posągów i statuetek $z$ brązu oraz przedmiotów $z$ wyposażenia załogi wydobyto z niego liczny zespół rzeźb marmurowych (il. 4) ${ }^{136}$. Na podstawie analizy znalezisk stwierdzono, że zatopiony około 70 roku p.n.e. statek zmierzał z Morza Egejskiego w kierunku Italii, a przewożony przez niego ładunek dzieł sztuki greckiej był zapewne wojennym łupem jednego z rzymskich wodzów ${ }^{137}$. W starożytnych źródłach pisanych wspomina się o wielu takich spoliach, a jedno z nich Loyrette wskazał wprost jako antyczną analogię dla obiektów z kolekcji Amotana ${ }^{138}$. Kiedy porówna się obiekty z pro-

${ }^{134}$ Schama (Inventory, s. 18-23) nadał swojemu tekstowi formę narracyjną, typową dla historycznej powieści erudycyjnej w stylu Umberta Eco, Artura Pérez-Reverte czy nawet Dana Browna; esej Goddio Discovering a Shipwreck, s. 24-27, ma charakter bardziej naukowy; a z kolei rozważania Loyrette'a, On the Name..., można uznać za syntezę obu postaw.

135 J. Marchant, Exploring the Titanic of the Ancient World, "Smithsonian Magazine” $2015,10(45)$, s. 56-69.

136 G.D. Weinberg et al., The Antikythera shipwreck reconsidered, Philadelphia 1965; P.C. Bol, Die Skulpturen des Schiffsfundes von Antikythera, Berlin 1972; E. Vlachogianni, Sculpture, w: The Antikythera Shipwreck: the ship, the treasures, the mechanism, red. N. Kaltsas, E. Vlachogianni, P. Bouyia, Athens 2012, s. 62-115.

${ }^{137}$ Przeznaczonym do ekspozycji w trakcie triumfu i ustawienia w jednej ze świątyń Wiecznego Miasta, zob. A. Mastrocinque, The Antikythera Shipwreck and Sinope's Culture during the Mithridatic Wars, w: Mithridates VI and Pontic Kingdom, red. J.M. Højte, Aarhus-Lancaster 2009, s. 313-319; lub w prywatnej kolekcji, jak sądzi N. Himmelmann, Mahdia und Antikythera, w: Das Wrack. Der antike Schiffsfund von Mahdia, red. G. Hellerkemper-Salies, Köln 1994, s. 849-855; por. J.J. Pollitt, The Impact of Greek Art on Rome, „Transactions of the American Philological Association” 1978, 108, s. 155-174.

${ }_{138}$ Loyrette, On the Name..., s. 14; miała nią być monumentalna grupa Skopasa (Młodszego?), ustawiona około 30 roku p.n.e. przez Domicjusza Ahenobarbusa w świątyni Neptuna przy Cyrku Flaminiusza w Rzymie - dzieło o podobnie złożonej kompozycji i mitologiczno-morskiej tematyce co wytwory Hirsta; zob. Pliniusz, Historia Naturalna, XXXVI.26; 
jektu Hirsta z rzeźbami odnalezionymi koło greckiej wyspy, zależność między realnym a fikcyjnym wrakiem staje się oczywista. Dość dobrze zachowane antyczne posągi i statuetki wykonane $z$ brązu krótko po odkryciu zostały odrestaurowane i trafiły na stałą wystawę w Narodowym Muzeum Archeologicznym w Atenach. Dużo liczniejsze figury z marmuru, niemal bez wyjątku noszące ślady destrukcyjnej działalności organizmów morskich, przez długie dziesięciolecia pozostawały poza ekspozycją, porzucone na niedostępnym dla zwiedzających dziedzińcu. Kolejni kustosze uznawali je z powodu tych zniszczeń za zbyt mało estetyczne, by ustawić je obok znalezionych pod ziemią arcydzieł sztuki greckiej, wypełniających główne sale muzeum. Interesuiące jest to, że wśród tych ostatnich znajdowało się wiele rzeźb mechanicznie uszkodzonych, ale zachowujących gładką rzeźbiarską fakturę marmuru. Dopiero całkiem niedawno, w czasie, gdy prace Hirsta nad jego projektem były jeszcze w powijakach, wiele z marmurowych posągów z Antikythery zostało włączonych do monograficznej wystawy tego wraku w sposób podkreślający ich „ekspresjonistyczną" fakturę (il. 4) ${ }^{139}$. W podsumowaniu odcinka serialu Jacques'a Cousteau, o którym była już mowa w kontekście zapożyczeń formalno-treściowych filmu Hobkinsona, pokazano francuskiego pioniera archeologii podwodnej podczas spaceru wzdłuż szpaleru nadgryzionych zębem czasu posągów, stojących w zapomnieniu na dziedzińcu ateńskiego muzeum. Wygłaszany przez niego komentarz mógłby zostać użyty jako motto „Treasures...": „Czasami te fragmenty są tak bardzo uszkodzone, że niemożliwa jest ich rekonstrukcja; groteskowe parodie zamysłu artysty, dziedzictwo podwodnego świata" ${ }^{\prime 140}$.

Coś, co dla Cousteau było groteskowym wynaturzeniem antycznych dzieł, Hirst uczynił integralną cechą swoich wytworów, w ramach przewrotnej gry, mającej na celu nie tyle uprawomocnienie fikcji, że widz wystawy i filmu ma do czynienia ze starożytnymi oryginałami, ile postawienie istotnego znaku zapytania odnośnie do naszego obcowania z reliktami przeszłości. Hirst mówi o tym otwarcie: „[...] większość wydarzeń z przeszłości jest trudna do uwierzenia. Widząc Wenus z Milo, można pomyśleć, że ktoś umyślnie utrącił jej

L. Richardson, Jr., A New Topographical Dictionary of Ancient Rome, Baltimore-London 1992, s. 267; P.J.E. Davies, Architecture and Politics in Republican Rome, Cambridge-New York 2017, s. 126-128.

139 The Antikythera Shipwreck: the ship, the treasures, the mechanism, red. N. Kaltsas, E. Vlachogianni, P. Bouyia, Athens 2012. Na ekspozycji, prezentowanej poza Atenami jeszcze w kilku miejscach na świecie, w tym w Bazylei i Pekinie, wystawiono także obiekty codziennego użytku, odnalezione w miejscu zatonięcia statku. Ten i szereg innych pomysłów aranżacyjnych można odnaleźć w późniejszej weneckiej wystawie brytyjskiego artysty.

${ }^{140}$ The Cousteau Odyssey..., 53-54 min 


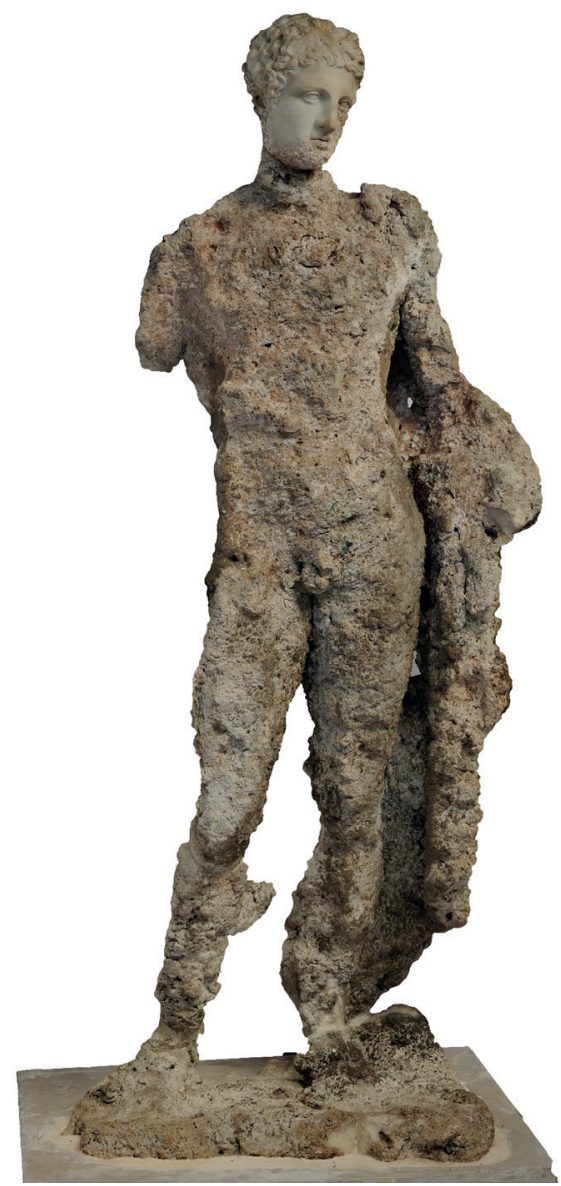

4. Posąg Hermesa w typie Richelieu z wraku koło Antikythery, pocz. I w. p.n.e., marmurowa kopia oryginału brązowego z ok. 350 r. p.n.e., Ethnikó Archaiologikó Mouseío, Athina [Narodowe Muzeum Archeologiczne w Atenach], nr inw. EAM 2774

ręce..." ${ }^{\prime 141}$. W tym pozornie banalnym stwierdzeniu pobrzmiewają głębsze echa drastycznie odmiennego tradycyinego rozumienia dzieła sztuki. Z perspektywy klasycznej estetyki całości uszkodzenie rzeźby musiało być skutkiem działania czynników zewnętrznych wobec procesu tworzenia i ekspozycji, takich jak obrazoburstwo czy siły natury. W związku z tym niemożliwe jest uznanie ubytków za element strategii artystycznej, tak istotny dla dominującej później estetyki

141 Treasures..., reż. S. Hobkinson, 73 min. 
fragmentu. Wyjątkiem od tej zasady było tworzenie rozmyślnie uszkodzonych posągów all'antica, co zdarzało się całkiem często w końcu XV i w XVI wieku, $z$ inicjatywy albo samych twórców, albo zamawiających. Wskazuje to, że zarówno w przypadku oryginalnych posągów, wydobywanych spod ziemi, jak i nowożytnych, wtórnie uszkadzanych, fragmentację uznawano za świadectwo ich dawności ${ }^{142}$. Hirst wykorzystuje ten dyskurs - w jego fikcji wiek dzieł jest gwarantowany nie tylko przez wydobycie ich spod wody rękami archeologów, ale też uszkodzenia na skutek działania morskiego żywiołu i stworzeń go zamieszkujących.

Przykładem tego jest filmowe znalezisko brązowego bezgłowego posągu demona $^{143}$. Widoczne na ekranie uszkodzenia posągu są przedstawiane widzowi w sposób już znany - jako znaki odciśnięte przez czas na substancji zabytku, świadczące o jego autentyczności, dodatkowo potwierdzonej przez obiekt pochodzący z niezależnych badań. Jest nim rzeźbiona głowa, którą archeolodzy brytyjscy mieli odnaleźć w roku 1932 w Mezopotamii ${ }^{144}$. Została ona uobecniona przed oczami widza przez odpowiednio spreparowaną fotografię momentu jej odkrycia, którą ekspedycyjna historyk sztuki wykorzystuje do rekonstrukcji statuy $z$ „Apistosa”. Dokonuje tego w sposób typowy dla swej profesji, przeprowadzając formalno-treściową analizę i porównując styl obu obiektów. Podsumowujący to z offu komentarz Hirsta stanowi wykładnię jednego z głównych wątków jego przedsięwzięcia: „Choć może wydawać się całością, historia jest tworzona $z$ fragmentów" ${ }^{\prime 14}$. Uszkodzenia i zniszczenia mogą być świadectwem autentyczności rzeczy, ale jednocześnie stanowią poważne wyzwanie dla badacza odtwarzającego ich historię. Jest to doskonale widoczne w zabiegach mających na celu (re)konstrukcję statku Amotana.

Większość historycznych wraków, rozumianych jako zalegające na dnie pozostałości jednostek morskich, ma charakter czysto wirtualny, gdyż przeważnie nie zachowują się ich kadłuby ${ }^{146}$, a jedynie ładunek ${ }^{147}$. Łatwo więc

${ }^{142}$ L. Freedman, Michelangelo's Reflection on Bacchus, „Artibus et Historiae” 2003, 24(47), s. 124-125.

${ }^{143}$ Hirst et al., Treasures from the Wreck..., s. 262 (Submerged Demon with Bowl, fotos); to pomniejszona wersja z brązu masywnej figury ustawionej w dziedzińcu Palazzo Grassi, której oryginał znajduje się obecnie w Las Vegas (zob. wyżej, przyp. 6 i 25).

${ }^{144}$ Ibidem, s. 156; zgodnie z fikcyjną opowieścią głowa nigdy nie znajdowała się w kolekcji Amotana, więc „renesansowego” rysunku brak.

145 Treasures..., reż. S. Hobkinson, 34-35 min.

$146 \mathrm{~W}$ ciepłych i dobrze nasłonecznionych wodach drewno jest pożerane w błyskawicznym tempie przez małże z rodziny świdrakowatych (Teredo navalis), zob. K. Muckelroy, Maritime Archaeology, Cambridge 1978, s. 53.

147 Poza tymi znajdowanymi w chłodniejszych i mniej natlenionych wodach, jak choćby słynny „Waza”, zob. G.P.B. Naish, The “Wasa”, her place in history, London 1968. 
zrozumieć, dlaczego „Apistos” stał się centralnym elementem przedsięwzięcia Hirsta, gdyż jego badania - choć noszą znamiona postępowania naukowego - stanowią nieustannie manifestację wiary w "to, co nie istnieje”. Widać to choćby przy interpretacji wydobytego przez nurków masywnego metalowego bolca, przypominającego te, których w czasach rzymskich używano do łączenia elementów kilu ${ }^{148}$. Realizatorzy projektu nieprzypadkowo spreparowali właśnie ten obiekt, gdyż pochodząc ze strukturalnie kluczowego fragmentu kadłuba, umożliwiał jego rekonstrukcję. Dokonano jej, wykorzystując metodę odtwarzania całości z zachowanej części, znaną archeologom i paleontologom od czasów braci Cuvier ${ }^{149}$. Posiłkowano się przy tym odniesieniami do starożytnych źródeł ikonograficznych i pozostałości innych rzymskich statków handlowych, przede wszystkim „Madrague de Giens”150. Interpretacji znalezisk dokonano już po sezonie badawczym w specjalistycznym centrum badań podwodnych na University of Southampton ${ }^{151}$, notabene rzeczywiście istniejącym ${ }^{152}$. Stosując przedstawioną tutaj metodykę badań, ustalono, że "Apistos” musiał być największym statkiem starożytnym $^{153}$. Jak ujął to Julian Whitewright, kierujący wspomnianą instytucją: „Statek tej wielkości mógł istnieć, nie wykraczał bowiem poza możliwości technologiczne epoki"154. Dla pokazania jego rozmiarów realizatorzy filmu dokonali cyfrowej rekonstrukcji, umieszczając ją na powierzchni morza, ustawiwszy kilka postaci ludzkich na pokładzie. „Tak jak w Hollywood” komentuje efektowną wizualizację Lerner.

Te dociekania stanowią przykład tworzenia przez archeologię wizji przeszłości z fragmentów, a więc koncepcji stanowiącej podstawę projektu Hirsta. Kolejnym przykładem wykorzystania tej zasady na potrzeby artystycznej narracji są przedstawione przez Loyrette'a w erudycyjnej grze prawdy i fikcji archiwistyczne badania starożytnych dokumentów, mających się odnosić do

148 Treasures..., reż. S. Hobkinson, 23-24 min.

149 G. Dawson, Show me the bone: reconstructing prehistoric monsters in nineteenth-century Britain and America, Chicago 2016, s. 18-34.

150 A. Tchernia, P. Pomey, A. Hesnard, L'apave romaine de la Madrague de Giens, Paris 1978.

151 Treasures..., reż. S. Hobkinson, 24-26 min.

${ }^{152}$ Dzięki temu jest to jeden $z$ najbardziej przekonujących pod względem metodyki naukowej elementów postępowania badawczego fikcyjnej ekspedycji Lernera.

${ }^{153}$ K. Hopkins, Models, Ships and Staples, w: Trade and Famine in Classical Antiquity, red. P. Garnsey, C.R. Whittaker, Cambridge 1983, s. 97-102; A. Wilson, The economic influence of developments in maritime technology in antiquity, w: Maritime Technology in the Ancient Economy: Ship Design and Navigation, red. W.V. Harris, K. Iara, Portsmouth, Rhode Island 2011, s. 213-217.

154 Treasures..., reż. S. Hobkinson, $25 \mathrm{~min}$. 
„Apistosa"155. Najważniejszy z nich jest przekaz autorstwa niejakiego Lucjusza Longinusa, ponoć zamieszczony w Uczcie mędrców Atenajosa z Naukratis, tekście znanym $z$ jedynego, i to niepełnego, średniowiecznego manuskryptu ${ }^{156}$. Historyczność Longinusa potwierdza wzmianka w (oczywiście fikcyjnym) papirusie znalezionym w Myos Hormos na egipskim wybrzeżu Morza Czerwonego ${ }^{157}$. Miał on być żeglarzem, który widział i odwiedził statek Amotana, dzięki czemu jego opis jest bardzo szczegółowy. Nie tylko podaje wymiary statku i analizuje szczegóły jego konstrukcji, ale też wskazuje, co znajdowało się w ładowni. Piszący dla Hirsta autorzy wykorzystują to do rozważań na temat wielkości, pojemności i jakości wykonania statku, a także wysokiego poziomu komfortu, który zapewniał swoim pasażerom, w tym przyzwyczajonemu do luksusu Amotanowi ${ }^{158}$.

Zanim jeszcze wrak został zidentyfikowany i zrekonstruowany, pokazano, jak członkowie filmowej ekspedycji - dokonujący kolejnych znalezisk na dnie morza, ale niemający żadnych danych do rozpoznania ich kontekstu - pozostawali zagubieni w czasoprzestrzeni. Rozproszenie obiektów na dnie nie pozwalało im się zorientować, czy mają do czynienia z reliktami jednej, czy kilku zatopionych jednostek. Nie przemawiały jednoznacznie również same

155 Loyrette, On the Name..., s. 13, ogólnie o manuskryptach wspomina też Goddio, Discovering a Shipwreck, s. 24-25.

156 Podstawowe informacje na temat tekstu Atenajosa podaje M. Landfester, Athenaios [3] aus Naukratis (Ägypten), w: Der neue Pauly. Supplemente, t. 2: Geschichte der antiken Texte: Autoren- und Werklexikon, red. M. Landfester, B. Egger, Stuttgart 2007, s. 88-89.

157 Zgrabnie tutaj dostosowano do narracji Hirsta realia naukowych badań nad starożytnością. Przytłaczająca więlkszość antycznych źródeł literackich znana jest bowiem jedynie ze średniowiecznych odpisów, podczas gdy nieliczne oryginały, w formie mniej lub bardziej fragmentarycznej, najczęściej są znajdowane w suchych piaskach Egiptu lub Izraela; por. M.S. West, Textual Criticism and Editorial Technique Applicable to Greek and Latin Texts, Stuttgart 1973; R.S. Bagnall, Reading Papyri, Writing Ancient History, London 1995.

158 Geuna, The Coral Diver, s. 10; Goddio, Discovering a Shipwreck, s. 24; Loyrette, On the Name..., s. 13. Źródłem inspiracji i punktem odniesienia dla koncepcji takiej jednostki są ogromne okręty i statki flot hellenistycznych z III wieku p.n.e., zob. W.M. Murray, The Age of Titans: The Rise and Fall of the Great Hellenistic Navies, Oxford-New York 2012, s. 170-207; wielki statek, zbudowany przez Werresa dla transportu dzieł sztuki z Sycylii, zob. Cyceron, Przeciw Werresowi, II.4.23; M.M. Miles, Cicero's Prosecution of Gaius Verres: A Roman View of the Ethics of Acquisition of Art, „International Journal of Cultural Property" 2002, 1(11), s. 28-49 oraz gigantyczne luksusowe barki Kaliguli z jeziora Nemi. Były to jak najbardziej rzeczywiste obiekty, wzmiankowane w źródłach pisanych, a w ostatnim przypadku szczegółowo przebadane przez archeologów, zob. G. Ucelli, Le navi di Nemi, Roma 1950; D.N. Carlson, Caligula's Floating Palaces, „Archaeology” 2002, 3(55), s. 26-31. 
obiekty, utrzymane w różnej stylistyce ${ }^{159}$. Sytuacja uległa zmianie dopiero po odnalezieniu monety rzymskiej z czasów Nerona i stwierdzeniu, że wszystkie znaleziska pochodzą z jednego wraku, czyli z tzw. zespołu zwartego ${ }^{160}$. Tym mianem określa się nagromadzenie artefaktów zdeponowane w ziemi lub na dnie morza w jednym momencie. W związku z tym nie są wymieszane z wcześniejszymi ani późniejszymi reliktami ludzkiej działalności, choć w wypadku zatopionych statków handlowych często pochodzą z różnych miejsc ${ }^{161}$. Rozpoznanie kontekstu nie tylko dało odpowiedź na fundamentalne dla badacza przeszłości pytania: „kiedy?” i „gdzie?”, ale przybliżyło też do rozstrzygnięcia równie istotnych kwestii: „co?” i „kto?”. Umożliwiło to odniesienia do źródeł pisanych i artystycznych $z$ epoki oraz całokształtu wiedzy na jej temat ${ }^{162}$. Dzięki temu można było sprecyzować problem badawczy: „Co tak duży statek $z$ tak cennym ładunkiem robił u wybrzeży Afryki Wschodniej?"163.

Szukając odpowiedzi na to pytanie, podjęto pracę w archiwach i bibliotekach, starając się znaleźć informacje na temat największego statku starożytności. Jak wskazywano wcześniej, według Goddio ten etap działań miał miejsce na początku projektu badawczego, ale przy realizacji filmu kolejność postępowania zmieniono, niewątpliwie dla osiągnięcia większego efektu dramatycznego. Po bezowocnych analizach dzieł rzymskich historyków Weiss postanowił zapoznać się z legendami zachowanymi na kartach antycznych antologii i powieści ${ }^{164}$. Czynił to zgodnie $z$ założeniem, że obec-

159 Treasures..., reż. S. Hobkinson, $17 \mathrm{~min}$.

160 Goddio, Discovering a Shipwreck, s. 26.

161 Treasures..., reż. S. Hobkinson, $19 \mathrm{~min}$.

${ }^{162}$ Ibidem, $20 \mathrm{~min}$. Sugestia ekspedycyjnej historyk sztuki, że badacze mają do czynienia $z$ transportem dzieł sztuki przeznaczonych na handel, została odrzucona z powodu braku antycznych informacji źródłowych o tego typu aktywności na Oceanie Indyjskim. W rzeczywistości istnieje wzmianka o posągach eksportowanych drogą morską z Egiptu na dwór jednego z władców południowej Arabii, zob. The Periplus Maris Erythrei with Introduction, Translation, and Commentary, red. i tłum. L. Casson, Princeton 1989, s. 41; o handlu dziełami sztuki por. W. Brillowski, Zbytek, status, znawstwo. O kolekcjonerstwie sztuki greckiej w Rzymie u schyłku republiki i w początkach pryncypatu, w: Zbytek i ubóstwo w starożytności i średniowieczu, red. L. Kostuch, E. Ryszewska, Kielce 2010, s. 161-171.

163 Treasures..., reż. S. Hobkinson, $21 \mathrm{~min}$.

${ }^{164}$ Ibidem, 26-27 min; nie jest to sytuacja niespotykana na gruncie badań nad antykiem, gdyż poważni uczeni nieraz próbowali w ten sposób uzupełniać niedostatki antycznych źródeł historycznych, szczególnie odnośnie do na wpół legendarnej postaci Aleksandra Wielkiego; zob. R. Stoneman, Alexander the Great: A life in legend, New Haven-London 2010; The Alexander Romance in Persia and the East, red. R. Stoneman, K. Erickson, I. Netton, Groningen 2012. 
ność jakiegoś niezwykłego motywu czy postaci w różnych mediach, w tym także w literaturze fantastycznej i dziełach sztuki, świadczy o ich kulturowej ważności. Dzięki temu można przyjąć, że opowieść nieprawdopodobna, ale nie niemożliwa, może zawierać w sobie elementy prawdy historycznej. „I tak odkryłem dzieje Aulusa Kalidiusza Amotana!” - oznajmia z triumfem w głosie niemiecki entuzjasta ${ }^{165}$. Tu w sukurs przychodzi mu autorytet kolejnego autentycznego naukowca - filolog klasycznej doktor Lisy Hau z University of Glasgow, według której: „«Apistos» mógł istnieć, ale to, co konkretnie przewoził, mogło zostać zmitologizowane"166. Pokłosiem tej mitologizacji miały być eksploracje dwudziestowiecznych poszukiwaczy skarbów ${ }^{167}$, na temat których $z$ dystansem wypowiada się kierownik filmowej ekspedycji. Deklaruje swoją wiarę w moc nauki, w postępowanie badawcze oparte na źródłach oraz dowodach, i podkreśla, patrząc prosto w obiektyw kamery: „My polujemy na wiedzę, nie na skarby”. Weiss odpowiada na to chwilę później: „Zaczynałem wierzyć, że wraku nie odnaleziono nie dlatego, iż był mitem, ale dlatego, że szukano w niewłaściwym miejscu"168.

Rozłam wewnątrz filmowej ekipy dotyczy nie tylko stosunku do nauki i legend, ale także, co bezpośrednio $z$ tego wynika, sposobu postępowania względem odkrytych obiektów, szczególnie tych najcenniejszych. Pragnący je odpowiednio zadokumentować naukowiec Lerner odpiera odruch ich natychmiastowego wydobycia, na co odpowiada mu goniący za mitami i skarbami Weiss: „Dla mnie oczywistym rozwiązaniem jest wyciągnięcie wszystkiego na powierzchnię jak najszybciej"169. To odwieczny problem w dziejach archeologii, szczególnie istotny w XIX i początkach XX wieku ${ }^{170}$. Jego pokłosie obserwujemy i dzisiaj w zachowaniu niektórych archeologów, ale przede

165 Treasures..., reż. S. Hobkinson, $27 \mathrm{~min}$.

166 Ibidem, 28-29 min.

167 Zilustrowane ujęciami z fikcyjnego wydania kroniki filmowej „American Newsreel” z roku 1962, do których podłożono głos lektora, opowiadającego o poszukiwaniach skarbu Amotana, prowadzonych przez kapitana George'a Knowlesa. W rzeczywistości te zdjęcia pochodzą z filmu szpiegowskiego The Silent Enemy (reż. W. Fairchild, 1958), opowiadającego o walkach brytyjskich i włoskich płetwonurków w wodach Gibraltaru i hiszpańskiego Algeciras w czasie drugiej wojny światowej.

168 Treasures..., reż. S. Hobkinson, $30 \mathrm{~min}$.

169 Ibidem, 42-43 min.

170 Por. C. Colwell-Chanthaphonh, T.J. Ferguson, Trust and archaeological practice: towards a framework of Virtue Ethics, w: The Ethics of Archaeology: Philosophical Perspectives on Archaeological Practice, red. C. Scarre, G. Scarre, Cambridge 2006, s. 115-116. 
wszystkim w powszechnym odbiorze dyscypliny, gdzie rangę znalezisk mierzy się głównie ich wartością materialną ${ }^{171}$, a nie naukową ${ }^{172}$.

Hirst, choć czyni zatopiony statek bytem czysto wirtualnym, to jednocześnie wypełnia go natłokiem konkretnych i namacalnych obiektów - zarówno przedmiotów codziennego użytku, jak i wystawnych dzieł sztuki, często wykonanych $z$ drogocennych materiałów ${ }^{173}$. Pozwala to na snucie wizji ładunku „Apistosa” jako całościowej kolekcji, będącej wyrazem charakteru, doświadczeń i smaku Amotana ${ }^{174}$. Do pewnego stopnia przypomina ona wczesne muzea, w których zbierano różnorakie cuda sztuki i natury, realizując obsesję mikrokosmosu - gromadzenia, posiadania i ogarnięcia w jednym zbiorze całego świata $^{175}$. Różnorodność nie jest jednak dla Hirsta wartością samą w sobie, dlatego zestawia dzieła sztuki i rzemiosła w odmiennych stylach, budzących skojarzenia z kulturami Egiptu, Indii, Chin, zachodniej Afryki, Grecji czy Rzymu, szukając między nimi podobieństw strukturalnych i treściowych. Od Amotana, będącego jego alter ego tylko do pewnego stopnia, odróżnia go

${ }^{171}$ K. Romey, 9 Dazzling Discoveries of Ancient Gold Treasure, „National Geographic”, dostępnyw internecie: < https://www.nationalgeographic.com/news/2017/10/ancient-gold-treasure-archaeology-egypt> [dostęp: 2 kwietnia 2020].

${ }^{172} \mathrm{~W}$ realiach współczesnej archeologii bezpośrednio wiąże się z tym konieczność zabezpieczenia „skarbów” przed przedwczesnym upowszechnieniem wiedzy o ich znalezieniu, czego skutkiem mogłoby być przyciągnięcie uwagi rabusiów, nielegalnych poszukiwaczy skarbów czy wreszcie osób publicznych, próbujących zbić na znaleziskach kapitał polityczny. Owocuje to zniszczeniem stanowiska, grabieżą znalezisk czy wreszcie utrudnieniem pracy przez zalew fotoreporterów, kamerzystów i dziennikarzy, zob. Archaeology and Capitalism, red. Y. Hamilakis, P. Duke, Walnut Creek 2007.

173 Calchi Novati, Staging the Wreck..., s. 23-24.

174 Treasures..., reż. S. Hobkinson, 38-39 min.; według Geuna, The Coral Diver, s. 11, to zwierciadło pasji Amotana-Hirsta, jego ekstrawaganckiego smaku, uwielbienia piękna, często manifestującego się w sposób nieoczywisty, eklektyczny w zróżnicowaniu czasowym, przestrzennym i kulturowym; por. W. Muensterberger, Collecting. An Unruly Passion: Psychological Perspectives, Princeton 2014, s. 3-13; K. Pomian, Zbieracze i osobliwości. Paryż - Wenecja, XVI-XVIII wiek, Lublin 2001, słusznie krytykuje to jako „prymitywną psychologię".

${ }^{175}$ Loyrette, On the Name..., s. 16, analizuje kolekcjonerstwo Amotana w odniesieniu do ścisłych związków między nowożytnymi oraz nowoczesnymi wyprawami odkrywczymi i zdobywczymi a rozwojem instytucji muzealnych w Europie. Literatura na ten temat jest rozległa; szczególnie w ostatnim dwudziestoleciu nastąpił przyrost publikacji pisanych z perspektywy postkolonialnej, zob. R.G.W. Anderson et al., Enlightning the British: Knowledge, discovery and the museum in the eighteenth century, London 2003; T. Bennett, Pasts Beyond Memory: Evolution, Museums, Colonialism, London-New York 2004; M. Díaz-Andreu, A World History of Nineteenth-Century Archaeology: Nationalism, Colonialism, and the Past, Oxford-New York 2007. 
również to, że nie interesują go wyłącznie mirabilia, ale wszystkie przedmioty pochodzące $z$ wraku, w tym „banalne” narzędzia i naczynia należące do członków załogi. Nie świadczy to jednak o jego zagubieniu w pasji gromadzenia wszystkiego, gdyż artysta jest aż nazbyt świadom zagrożeń, które temu towarzyszą ${ }^{176}$. Wynika to przede wszystkim z przyjęcia refleksyjnej postawy względem wszelkich reliktów przeszłości, niwelującej różnice w stosunku do rzeczy, charakteryzujące historię sztuki i archeologię.

W tym świetle należy też spoirzeć na hierarchizowanie znalezionych przedmiotów, nie ze względu na ich artyzm, ale materiał, z którego zostały wykonane. Artysta, choć eksponuje wszystkie obiekty z fikcyjnego wraku, to szczególny nacisk kładzie na prezentację tych, które w powszechnym odbiorze postrzegane są jako wartościowe i drogocenne. Jest sprawnym biznesmenem, w pełni świadomym, jak złoto przyciąga kolekcjonerów jego twórczości, oraz osobowością medialną, umie wykorzystać fascynację bogactwem dla zwiększenia liczby widzów swojego filmu czy zwiedzających wystawę. Dla niego samego złoto jest jednak czymś więcej, przez co wpisuje się doskonale $\mathrm{w}$ treściowy program jego przedsięwzięcia. Po pierwsze, stanowi istotny element $\mathrm{w}$ dyskursie wiarygodności, w nawiązaniu do doskonale znanego $\mathrm{z}$ dziejów archeologii „syndromu Schliemanna”. W filmie odnosi się do tej kwestii Weiss, mentalny spadkobierca odkrywcy skarbów Troi i Myken, mówiąc: „Gdy opierasz się na legendach i mitach, ludzie nie biorą Cię na poważnie, ale tak ogromna ilość złota nagle sprawiła, że ta historia zyskała nowe życie $^{\prime 177}$. Po drugie, jak podkreśla sam Hirst w jednym ze swych filmowych komentarzy, złoto wymyka się wszechogarniającej destrukcyjnej sile przyrody i upływającego czasu, co w połączeniu z blaskiem daje mu mityczną czy wręcz religijną moc.

W podsumowaniu należy podkreślić, że omawiany projekt artystyczny jest przeniknięty tak istotną dla współczesnej humanistyki problematyką materializmu oraz pamięci, jednak bez szumnych deklaracji i nadmiernego eks-

${ }^{176}$ Ilustruje to zamieszczona w filmie opowieść Hirsta o jego sąsiedzie z czasów młodości, niejakim Barnesie, który zgromadził tak wiele przedmiotów ze swego życia, że ostatecznie został przytłoczony ich masą - znikł, pozostawiając za sobą zamienione w rupieciarnię mieszkanie. Ta historia towarzyszy artyście od dawna, a jej szczegóły zacierają się na przestrzeni dziesięcioleci, prawda miesza się z fikcją, a jej bohater staje się (a może od początku był?) figurą myślową, chwilami Nemezis, a kiedy indziej alter ego artysty. Powraca on nieustannie w kilku wywiadach, które z artystą na przestrzeni ostatniej dekady XX wieku przeprowadził Gordon Burn, zob. Hirst, Burn, On The Way..., s. 51-52, 108, 124, 134.

177 Treasures..., reż. S. Hobkinson, $50 \mathrm{~min}$. 
plikowania. W tym jego siła - Hirst pochyla się nad tymi kwestiami w sposób twórczy, pozwalając zrealizować się materii, rzeczom urzekać, a ich otoczeniu przemówić178. Minimalizując zewnętrzne w stosunku do dzieł opisy, wprzęga integralnie w swoją strategię artystyczną elementy tych działów humanistyki, które od stuleci zajmują się znajdywaniem, opisywaniem, klasyfikacją, konserwacją i interpretacją przedmiotów. Korzystając z dorobku historii sztuki i archeologii, dla których elementem wręcz definiującym jest zajmowanie się wieloaspektowością rzeczy, artysta pomaga im jednocześnie wyjść z cienia innych dyscyplin badawczych, które współcześnie zdominowały namysł nad materialnością przedmiotów ${ }^{179}$. To „zacofanie”, będące pokłosiem rzeczywistości poznawczej, w której badacz niejako naturalnie, często bezrefleksyjnie, pozostaje zanurzony w świecie rzeczy, paradoksalnie stanowi dla Hirsta siłę znawstwa czy archeologii, a nie ich słabość, jak mógłby to widzieć filozof czy socjolog. W jego artystycznym przedsięwzięciu istotną rolę pełni natura, przedstawiona nie tylko jako otoczenie obiektów, ale jako ich współtwórca, zgodnie z postulatami nowego materializmu, kontestującego wielowiekową humanistyczną tradycję przeciwstawiania jej kulturze ${ }^{180}$. Dlatego też twórca, mimo podkreślania malowniczości i unikatowości podwodnej przyrody, nie pozwala zapomnieć widzowi o jej niszczycielskim aspekcie, podejmując kluczowe dla jego twórczości wątki przemijania, rozpadu i śmierci. To właśnie dlatego po wraku niemal całkowicie nie ma śladu. Od początku do końca, mimo konsekwentnie rozwijanej iluzji naukowych „badan”, ich obiekt pozostaje ideą, marzeniem, opowieścią, symulakrum, modelem czy wręcz własną antytezą.

Hirst podkreśla, że sztuka od zarania swoich dziejów stanowiła podstawowe narzędzie obcowania $z$ tym, co nieuchwytne ludzkim zmysłom ${ }^{181}$. Dlatego według artysty jej kluczowym elementem jest wiara, określana nie przez to, co istnieje, ale to, czego nie ma. Wskazuje, że z tej samej perspektywy należy postrzegać przeszłość - jako rzecz samą w sobie nieobecną, z którą możemy obcować jedynie przez jej odpryski w postaci nadgryzionych zębem czasu artefaktów. Archeologia jest więc dla artysty nie tylko narzędziem kreacji jego projektu, ale staje się metaforą każdego procesu twórczego ${ }^{182}$. Jest jedną

178 C. Witmore, Archaeology and the New Materialisms, „Journal of Contemporary Archaeology" 2014, 1(2), s. 205.

179 Por. Olsen et al. Archaeology..., s. 1-2; Witmore, Archaeology..., s. 223.

180 Choat, Science..., s. 1037-1039.

181 Por. Pomian, Zbieracze..., s. 35-39.

182 Por. Olsen et al., Archaeology..., s. 157: „archaeology is itself a mode of cultural production, a creative enterprise of authoring, delivering goods and artifacts, and involving material modes of production". 
$z$ form dialogu $z$ niewidzialnym, jako nieustanne tworzenie i przetwarzanie obrazu nieosiągalnej dla zmysłów materii przeszłości. Wprawdzie może tworzyć modele dawnych epok, ale jej naukowe aspiracje do poszukiwania prawdy o minionych epokach są według Hirsta z góry skazane na porażkę. Dyscyplina procesu badawczego daje tylko złudzenie możliwości dotarcia do prawdy. W momencie gdy brak danych z poważnych źródeł, uczeni są zmuszeni sięgać po przekazy fantazyjne, by móc nadać sens swoim znaleziskom. Dlatego kluczowym elementem refleksji nad przeszłością jest dla artysty szukanie wspólnych, uniwersalnych elementów łączących ją z teraźniejszością ${ }^{183}$. Narzędziem do tego ma być emocjonalne i intelektualne zbliżenie, hermeneutyczne wczucie się czy wręcz utożsamienie podmiotu i przedmiotu badań za pośrednictwem artefaktów. Dlatego nawet adepci archeologii zgadzają się $z$ artystą co do jej mocy kreowania zajmujących opowieści o przeszłości, wykraczających poza fascynację urokami morskich głębi czy ekscytację odkryciem.

Archeolodzy w głębi serca także uwielbiają opowiadać, i choć w naszych narracjach przedstawiamy zabytki inaczej, to omawiana wystawa stanowi przypomnienie o tym, jaką mają moc oddziaływania i jakim zainteresowaniem cieszą się historie, które można wysnuć z rzeczy ${ }^{184}$.

\section{BIBLIOGRAFIA}

\section{LITERATURA}

Ajootian A., Praxiteles, w: Personal Styles in Greek Sculpture, red. O. Palagia, J.J. Pollitt, Cambridge 1996, s. 91-129

The Alexander Romance in Persia and the East, red. R. Stoneman, K. Erickson, I. Netton, Groningen 2012

Anderson R.G.W. et al., Enlightning the British: Knowledge, discovery and the museum in the eighteenth century, London 2003

Archaeology and Capitalism, red. Y. Hamilakis, P. Duke, Walnut Creek 2007

Bagnall R.S., Reading Papyri, Writing Ancient History, London 1995

Barnett S., Rhetoric's Nonmodern Constitution: Techne, Phusis, and the Production of Hybrids, w: Thinking with Bruno Latour in Rhetoric and Composition, red. P. Lynch, N. Rivers, Carbondale, IL, 2014, s. 81-96

Becatti G., Il culto di Ercole ad Ostia, „Bullettino della Commissione Archeologica Comunale di Roma" 1938-1939, 67, s. 37-60

Bennett J., The enchantment of modern life: Attachments, crossings, and ethics, Princeton 2001

183 Pisze też o tym Geuna, The Coral Diver, s. 11.

${ }^{184}$ Greene, Leidwanger, Damien Hirst's Tale..., s. 11. 
Bennett T., Pasts Beyond Memory: Evolution, Museums, Colonialism, London-New York 2004

Bethenod M., Preface, w: D. Hirst et al., Treasures from the Wreck of the Unbelievable, London 2017, s. 7

Bianchi Bandinelli R., Archeologia klasyczna jako historia sztuki, tłum. i posłowie W. Dobrowolski, Warszawa 1988

Boin D.R., A Hall for Hercules at Ostia and a Farewell to the Late Antique "Pagan Revival”, "American Journal of Archaeology” 2010, 2(114), s. 253-266

Bol P.C., Die Skulpturen des Schiffsfundes von Antikythera, Berlin 1972

Borges J.L., Oscar Wilde, Kwiat Coleridge'a, Sen Coleridge'a, „Więż” 1990, 2-3, s. 118-125

Borges J.L., Narrative Art and Magic, w: idem, Selected non-fictions, New York-London 1999, s. 75-82

Boysen B., The embarrassment of being human: A critique of new materialism and object-oriented ontology, „Orbis Litterarum” 2018, 73, s. 225-242

Brillowski W., Zbytek, status, znawstwo. O kolekcjonerstwie sztuki greckiej w Rzymie u schyłku republiki i w początkach pryncypatu, w: Zbytek i ubóstwo w starożytności i średniowieczu, red. L. Kostuch, E. Ryszewska, Kielce 2010, s. 161-171

Calchi Novati G., Staging the Wreck of the Unbelievable. Performing ideology: Imaginary surplus, alienation and anxiety, „Performance Research” 2019, 5(24), s. 21-26

Calligas P.G., Statue of a Young Athlete, w: Mind and Body: Athletic Contests in Ancient Greece, red. O. Tzachou-Alexandri, Athens 1989, s. 179-180

Carlson D.N., Caligula's Floating Palaces, „Archaeology” 2002, 3(55), s. 26-31

Choat S., Science, Agency and Ontology: A Historical-Materialist Response to New Materialism, „Political Studies” 2018, 4(66), s. 1027-1042

Coleridge S.T., Biographia Literaria or Biographical Sketches of My Literary Life and Opinions, t. 2, London 1817

Coleridge S.T., Poezje wybrane, wyb. i tłum. Z. Kubiak, Warszawa 1987

Colwell-Chanthaphonh C., T.J. Ferguson, Trust and archaeological practice: towards a framework of Virtue Ethics, w: The Ethics of Archaeology: Philosophical Perspectives on Archaeological Practice, red. C. Scarre, G. Scarre, Cambridge 2006, s. $115-130$

Cooper G.M., Astrology: The Science of Signs in the Heavens, w: The Oxford Handbook to Science and Medicine in the Classical World, red. P.T. Keyser, J. Scarborough, Oxford 2018, s. 381-407

Davies P.J.E., Architecture and Politics in Republican Rome, Cambridge-New York 2017

Dawson G., Show me the bone: reconstructing prehistoric monsters in nineteenth-century Britain and America, Chicago 2016

Díaz-Andreu M., A World History of Nineteenth-Century Archaeology: Nationalism, Colonialism, and the Past, Oxford-New York 2007

Dova S., Greek Heroes in and out of Hades, Lanham-Plymouth 2012

Drower M.S., Flinders Petrie: A Life in Archaeology, Madison 1995

Felch J., R. Frammolino, Chasing Aphrodite: The Hunt for Looted Antiquities at the World's Richest Museum, Boston-New York 2011 
Ferri A.J., Willing Suspension of Disbelief: Poetic Faith in Film, Lanham-New YorkPlymouth 2007

Flaubert G., Salambo, tłum. W. Rogowicz, Warszawa 1978

Freedberg D., Potęga wizerunków, tłum. E. Klekot, Kraków 2005

Freedman L., Michelangelo's Reflection on Bacchus, "Artibus et Historiae" 2003, 24(47), s. 121-135

Frel J., The Getty Bronze, Los Angeles 1978

Furtwängler A., Meisterwerke der griechischen Plastik. Kunstgeschichtliche Untersuchungen, t. 1-2, Leipzig 1893

Geuna E., The Coral Diver, w: D. Hirst et al., Treasures from the Wreck of the Unbelievable, London 2017, s. 10-11

Goddio F, Discovering a Shipwreck, w: D. Hirst et al., Treasures from the Wreck of the Unbelievable, London 2017, s. 24-27

Graf F., Magic in the Ancient World, Cambridge, MA, 1997

Green J., Maritime Archaeology: A Technical Handbook, San Diego 2004

Harman G., Tool-being: Heidegger and the metaphysics of objects, Chicago, IL, 2002

Harman G., Weird realism: Lovecraft and philosophy, Alresford 2012

Hemingway S., The Horse and Jockey From Artemision: A Bronze Equestrian Monument of the Hellenistic Period, Berkeley-Los Angeles-London 2004

Himmelmann N., Mahdia und Antikythera, w: Das Wrack. Der antike Schiffsfund von Mahdia, red. G. Hellerkemper-Salies, Köln 1994, s. 849-855

Hirst D., The Undersea Salvage Operation: Treasures from the Wreck of the Unbelievable, fot. C. Gerigk, S. Russell, London 2017

Hirst D., G. Burn, On The Way To Work, London 2001

Hirst D., A. Corry, Treasures from the Wreck of Unbelievable: One Hundred Drawings, London 2017

Hirst D. et al., Treasures from the Wreck of the Unbelievable, London 2017

Hopkins K., Models, Ships and Staples, w: Trade and Famine in Classical Antiquity, red. P. Garnsey, K. Hopkins, C.R. Whittaker, Cambridge 1983, s. 84-109

Kabbadias P., The Recent Finds off Cythera, "Journal of Hellenic Studies” 1901, 21, s. $205-208$

Karanika A., The End of the Nekyia: Odysseus, Heracles, and the Gorgon in the Underworld, „Arethusa” 2011, 1(44), s. 1-27

Landfester M., Athenaios [3] aus Naukratis (Ägypten), w: Der neue Pauly. Supplemente, t. 2: Geschichte der antiken Texte: Autoren- und Werklexikon, red. M. Landfester, B. Egger, Stuttgart 2007, s. 88-89

Latour B., We Have Never Been Modern, Cambridge, MA, 1993

Latour B., Reassembling the Social: An Introduction to Actor-Network Theory, Oxford 2005

Loyrette H., On the Name of, w: D. Hirst et al., Treasures from the Wreck of the Unbelievable, London 2017, s. 13-17

MacGregor N., A History of the World in 100 Objects, London 2010

Majkowski T.Z., W cieniu Białego Drzewa. Powieść fantasy w XX wieku, Kraków 2013 
Marchant J., Exploring the Titanic of the Ancient World, "Smithsonian Magazine" $2015,10(45)$, s. 56-69

Mastrocinque A., The Antikythera Shipwreck and Sinope's Culture during the Mithridatic Wars, w: Mithridates VI and Pontic Kingdom, red. J.M. Højte, Aarhus-Lancaster 2009, s. 313-319

Mattusch C.C., The Victorious Youth, Los Angeles 1997

Maurer K., Archeology as Spectacle: Heinrich Schliemann's Media of Excavation, "German Studies Review” 2009, 2(32), s. 303-317

Merlin A., Statues de bronze trouvées près de Mahdia, „Comptes rendus des séances de l'Académie des Inscriptions et Belles-Lettres" 1908, 4(52), s. 245-254

Miles M.M., Cicero's Prosecution of Gaius Verres: A Roman View of the Ethics of Acquisition of Art, "International Journal of Cultural Property” 2002, 1(11), s. $28-49$

Moscati S., The Phoenicians, Venezia 1988

Moscati S., E. Arslan, D. Vitali, The Celts: The Origins of Europe, New York 1991

Muckelroy K., Maritime Archaeology, Cambridge 1978

Muensterberger W., Collecting. An Unruly Passion: Psychological Perspectives, Princeton 2014

Murray W.M., The Age of Titans: The Rise and Fall of the Great Hellenistic Navies, Oxford-New York 2012

Naish G.P.B., The “Wasa”, her place in history, London 1968

Olsen B., In Defense of Things. Archaeology and the Ontology of Objects, Lanham, $\mathrm{MD}, 2010$

Olsen B. et al., Archaeology: The Discipline of Things, Berkeley-Los Angeles-London 2012

Petersen L.H., The Freedman in Roman Art and Art History, Cambridge 2011

Pollard A.M., Measuring the Passage of Time: Achievements and Challenges in Archaeological Dating, w: The Oxford Handbook of Archaeology, red. B. Cunliffe, C. Gosden, R.A. Joyce, Oxford-New York 2009, s. 123-139

Pollitt J.J., The Impact of Greek Art on Rome, „Transactions of the American Philological Association" 1978, 108, s. 155-174

Pollitt J.J., Art in the Hellenistic Age, Cambridge 2006

Pomian K., Zbieracze i osobliwości. Paryż-Wenecja, XVI-XVIII wiek, Lublin 2001

Posèq A.W.G., Caravaggio and the Antique, „Artibus et Historiae” 1990, 11(21), s. $147-167$

Richardson L., Jr., A New Topographical Dictionary of Ancient Rome, Baltimore-London 1992

Schama S., Inventory, w: D. Hirst et al., Treasures from the Wreck of the Unbelievable, London 2017, s. 18-23

Schmidt P., M. De La Garza, E. Nalda, I Maya, Milano 1998

Schulz E., Notes on the history of collecting and of museums, w: Interpreting Objects and Collections, red. S.M. Pearce, London-New York 2003, s. 175-187

Sharp J., Spirals and the Golden Section, „Nexus Network Journal” 2002, 1(4), s. 59-82

Smithson R., A Sedimentation of the Mind: Earth Projects, "Artforum” 1968, 1(7), s. $82-91$ 
Sparrow T., The end of phenomenology: Metaphysics and the new realism, Edinburgh 2014

Stevenson A., "We Seem to be Working in the Same Line”: A.H.L.F Pitt-Rivers and W.M.F. Petrie, „Bulletin of the History of Archaeology” 2012, 1(22), s. 4-13

Stewart A., Greek Sculpture: an Exploration, t. 2, Plates, New Haven-London 1990

Stoneman R., Alexander the Great: A life in legend, New Haven-London 2010

Tcherepashenets N., Place and displacement in the narrative worlds of Jorge Luis Borges and Julio Cortázar, New York 2008

Tchernia A., P. Pomey, A. Hesnard, L'apave romaine de la Madrague de Giens, Paris 1978

Torelli M., The Etruscans, Milano 2001

Tourtas A., The discovery of the Antikythera shipwreck: The social aspect, Southampton 2014 [University of Southampton, praca magisterska]

Traill D.A., Schliemann's “Dream of Troy”: The Making of a Legend, „Classical Journal" 1985, 1(81), s. 13-24

Ucelli G., Le navi di Nemi, Roma 1950

Underwater Archaeology: The Nautical Archaeological Society Guide to Principles and Practice, red. A. Bowens, Malden-Oxford 2009

Vlachogianni E., Sculpture, w: The Antikythera Shipwreck: the ship, the treasures, the mechanism, red. N. Kaltsas, E. Vlachogianni, P. Bouyia, Athens 2012, s. 62-115

Weinberg G.D. et al., The Antikythera shipwreck reconsidered, Philadelphia 1965

West M.S., Textual Criticism and Editorial Technique Applicable to Greek and Roman Texts, Stuttgart 1973

Wilk S.R., Medusa: Solving the Mystery of the Gorgon, Oxford 2000

Wilson A., The economic influence of developments in maritime technology in antiquity, w: Maritime Technology in the Ancient Economy: Ship Design and Navigation, red. W.V. Harris, K. Iara, Portsmouth, Rhode Island 2011, s. 211-233

Witmore C., Symmetrical archaeology: Excerpts of a manifesto, "World Archaeology” 2007, 4(39), s. 546-562

Witmore C.L., Archaeology and the New Materialisms, "Journal of Contemporary Archaeology" 2014, 1(2), s. 203-246

\section{ŹRÓDŁA ANTYCZNE}

Apollodoros, Biblioteka, wyd. jako Apollodorus, The Library, t. 1-2, tłum. i red. J.G. Frazer, Cambridge, MA, 1921

Apolloniusz, Wyprawa Argonautów, wyd. jako Apollonius Rhodius, Argonautica, tłum. i red. W.H. Race, Cambridge, MA, 2009

Arystoteles, Fizyka, wyd. jako Aristotle, Physics, vol. 1-2, tłum. i red. P.H. Wicksteed, F.M. Cornford, Cambridge, MA, 1934-1957

Cyceron, Przeciw Werresowi, wyd. jako Cicero, The Verrine Orations, t. 1-2, thum. i red. L.H.G. Greenwood, Cambridge, MA, 1928-1935

Hezjod, Teogonia, wyd. jako Hesiod, Theogony, Works and Days, Testimonia, tłum. i red. G.W. Most, Cambridge, MA, 2007 
Homer, Odyseja, wyd. jako Homer, Odyssey, t. 1-2, tłum. i red. A.T. Murray, popr. G.E. Dimock, Cambridge, MA, 1919

Lukan, Farsalia, wyd. jako Lucan, The Civil War, tłum. i red. J.D. Duff, Cambridge, MA, 1928

Owidiusz, Metamorfozy, ks. IV, wyd. jako Ovid, Metamorphoses, t. 1-2, tłum. i red. F.J. Miller, popr. G.P. Goold, Cambridge, MA, 1916.

Pauzaniasz, Opisanie Grecji, wyd. jako Pausanias, Description of Greece, t. 1-5, tłum. i red. W.H.S. Jones, Cambridge, MA, 1918-1935

Periplus Morza Erytrejskiego, wyd. jako The Periplus Maris Erythrei with Introduction, Translation, and Commentary, tłum. i red. L. Cassons, Princeton 1989

Pliniusz, Historia Naturalna, wyd. jako Pliny, Natural History, t. 1-10, tłum. i red. D.E. Eichholz, W.H.S. Jones, H. Rackham, Cambridge, MA, 1938-1962

\section{ŹRÓDŁA INTERNETOWE}

Cascone S., Damien Hirst's 60-Foot-Tall Demon Will Loom Over the Most Expensive, Art-Bedecked Hotel Renovation in Las Vegas's History, "Artnet News" 2019, 3 kwietnia, dostępny w internecie: < https://news.artnet.com/art-world/damienhirst-las-vegas-hotel-demon-1507594> [dostęp: 21 marca 2020]

Damien Hirst on his new shipwreck exhibition, „BBC News” 2017, 6 kwietnia <bbc.com/news/av/entertainment-arts-39519639/damien-hirst-on-his-newshipwreck-exhibition> [dostęp: 29 marca 2020]

Franck Goddio, Underwater Archaeologist, dostępnyw internecie: < https://www.franckgoddio.org/projects/sunken-civilizations/alexandria.html> [dostęp: 25 marca 2020]

Grecian, Cambridge Dictionary, dostępnyw internecie: $<$ https://dictionary.cambridge. org/pl/dictionary/english/grecian> [dostęp: 25 marca 2020]

Greene E.S., J. Leidwanger, Damien Hirst's Tale of Shipwreck and Salvaged Treasure, „American Journal of Archaeology Online” 2017, 13 grudnia, dostępny w internecie: <https://www.ajaonline.org/sites/default/files/1221\%20Greene_0.pdf> [dostęp: 12 marca 2019]

Hirst D., A. Haden-Guest, Interview, 23 listopada 2008, dostępny w internecie: $<$ https://www.interviewmagazine.com/culture/damien-hirst> [dostęp: 25 marca 2020]

Halperin J., Damien Hirst Created a Fake Documentary About His Fake Venice Show-and Now You Can See It on Netflix, „Artnet News” 2019, 5 stycznia, dostępny w internecie: < https://news.artnet.com/art-world/damien-hirst-created-fake-documentary-venice-show-can-see-netflix-1192922> [dostęp: 21 marca 2020]

Hirst D., The Severed Head of Medusa, Ashmolean Museum, 2018-2019, dostępny w internecie: <https://www.ashmolean.org/event/damien-hirst-medusa > [dostęp: 29 marca 2020]

Hirst D., Wunderkammer, „damienhirst”, 2015, dostępny w internecie: < http:// damienhirst.com/texts/2015/wunderkammer> [dostęp: 28 marca 2020]

Hirst D., Treasures from the Wreck of the Unbelievable [przewodniki], Palazzo Grassi, 2017, dostępny w internecie: <https://www.palazzograssi.it/en/exhibitions/past/ 
damien-hirst-at-palazzo-grassi-and-punta-della-dogana-in-2017-1/\# guide> [dostęp: 11 stycznia 2019]

Latson J., The Barbie Doll's Not-for-Kids Origins, „Time” 2015, 9 marca, dostępny w internecie: <https://time.com/3731483/barbie-history> [dostęp: 29 marca 2020]

Morgan T., Damien Hirst's Shipwreck Fantasy Sinks in Venice, „Hyperallergic” 2017, 10 sierpnia, dostępny w internecie: <https://hyperallergic.com/391158/damienhirst-treasures-from-the-wreck-of-the-unbelievable-venice-punta-della-doganapalazzo-grassi> [dostęp: 29 marca 2020]

Obrist H.U., D. Hirst, An Interview, 2007, dostępny w internecie: <http://www. damienhirst.com/texts/20071/feb--huo> [dostęp: 27 marca 2020]

Parke P., Damien Hirst accused of copying African art at Venice Biennale, CNN 2017 11 maja, dostępny w internecie: <https://edition.cnn.com/2017/05/10/africa/ damien-hirst-appropriation-venice-biennale> [dostęp: 3 kwietnia 2020]

Romey K., 9 Dazzling Discoveries of Ancient Gold Treasure, „National Geographic”, dostępny w internecie: <https://www.nationalgeographic.com/news/2017/10/ancient-gold-treasure-archaeology-egypt> [dostęp: 2 kwietnia 2020]

Sam Hobkinson, „IMDb”, dostępny w internecie: < https://www.imdb.com/name/ nm0387700/? ref_=tt_ov_dr> [dostęp 26 marca 2020];

Tim Cragg, "IMD $\overline{\mathrm{b}}$ ", dostępny w internecie: <https://www.imdb.com/name/ nm1145108/? ref_=fn_al_nm_1 $>$ [dostęp: 26 marca 2020].

Treasures from the Wreck of the Unbelievable (2017), „IMDb”, dostępny w internecie: <https://www.imdb.com/title/tt6980988/> [dostęp: 21 marca 2020]

Vogel C., Damien Hirst is Back With an Underwater Fantasy. Will Collectors Care?, „New York Times” 2017, 6 kwietnia, dostępny w internecie < nytimes. com/2017/04/06/arts/design/damien-hirst-francois-pinault-palazzo-grassi. html > [dostęp: 29 marca 2020]

Westfall M., The White Whale 2017, 13 listopada, dostępny w internecie: < http://gristle.com/2017/11/13/the-white-whale> [dostęp: 29 marca 2020]

\section{WYSTAWY}

Hirst D., „Romance in the Age of Uncertainity”, 9 września - 18 grudnia 2003, White Cube, Londyn, Wielka Brytania

Hirst D., „New Religion”, 13 października - 19 listopada 2005, Paul Stolper Gallery, Londyn, Wielka Brytania

Hirst D., „Relics”, 10 października 2013 - 22 stycznia 2014, Qatar Museums Gallery ALRIWAQ, Doha, Katar

Hirst D., „Treasures from the Wreck of the Unbelievable”, 9 kwietnia - 3 grudnia 2017, Punta della Dogana oraz Palazzo Grassi, Wenecja, Włochy

\section{FILMY I SERIALE}

Clash of the Titans, reż. D. Davis, 1981

The Cousteau Odyssey, seria 1, odc. 8, reż. J.-I. Cousteau, 1976 (1977)

Jason and Argonauts, reż. D. Chaffey, 1963 
Jungle Book, reż. W. Reitherman, 1967

The Silent Enemy, reż. W. Fairchild, 1958

Spiderman, reż. S. Raimi, 2002

Treasures from the Wreck of the Unbelievable, reż. S. Hobkinson, 2017

Wojciech Brillowski

Adam Mickiewicz University, Poznań

TREASURES FROM THE WRECK OF THE UNBELIEVABLE ARCHEOLOGY AS AN ELEMENT OF DAMIEN HIRST'S ARTISTIC STRATEGY

\section{Summary}

The most important element of Damien Hirst's multimedia project "Treasures from the Wreck of Unbelivable" was the exhibition, presented from April 9 to December 3, 2017 in Venice, in the galleries of the Pinault Foundation in Punta della Dogana and Palazzo Grassi. It was completed by several book publications and a 90-minute film of the same title, made available globally on the Netflix online platform on January 1 , 2018. The exhibition included over a hundred objects, mainly sculptures, made in various techniques and materials in a wide range of sizes. The film, stylized as a popular science documentary, presents the fictional story of their discovery and exploration at the bottom of the Indian Ocean, and their transport to Venice. It develops the main idea of the exhibition - a fictitious vision of the origin of these objects from an ancient wreck, filled with artistic collections, belonging to a fabulously rich ancient Roman freedman, with the significant name Cif Amotan II (anagram from "I am a fiction"). Realizing this fancy artistic vision, most of the works were made as if they had been damaged by the sea waves and overgrown with corals and other marine organisms. Hirst created a comprehensive and all-encompassing narrative using the principle of "voluntary suspension of unbelief," formulated by Samuel T. Coleridge. The artist sets himself and the viewer on a fantastic journey into the ancient past, taking up subjects central to his ouevre for decades: faith, relations of art and science, transience and death. He does this by means of numerous references to the artistic and mythological heritage of antiquity, not only Graeco-Roman, but also of other great cultures and civilizations.

Although the formal and technical aspects of the project will also be discussed, the main goal of the author is to analyze how Hirst used the knowledge of antiquity (classics) to create both the exhibition itself and the mockumentary. The artist made archeology an element binding his narrative together, showing in the film not only how artefacts were obtained from the bottom of the ocean. He also presented a number of tasks that scientists deal with at various stages of the project - from the first discovery, through interpretation and conservation, to the presenting at the museum-like exhibition. Of course, his purpose was not to create a study in the methodology of underwater exploration, but to reflect on the cognitive power of science examining re- 
mains of ancient times. By juxtaposing two possible attitudes towards relics of the past, i.e. the strict discipline of the scholar and the imagination of the treasure hunter, he concludes that narratives arising from them will both have the character of a mythical tale. The ontic status of the artefacts themselves, as the things of the past, left in a fragmentary state by the passage of time, sets all the stories related to them within the discourse of faith.

Keywords:

Hirst, mockumentary, science, art, myth, collecting, archaeology 